\title{
GEOMORPHOLOGICAL CLASSIFICATION AND LANDFORMS INVENTORY OF THE MIDDLE-ATLAS VOLCANIC PROVINCE (MOROCCO): SCIENTIFIC VALUE AND EDUCATIONAL POTENTIAL
}

\author{
Abdelmounji Amine ${ }^{1}$, Iz-Eddine El Amrani El Hassani², Toufik Remmal ${ }^{1}$, \\ Fouad El Kamel ${ }^{1}$, Benjamin Van WyK de Vries [i] $^{3}$, Pierre Boivin ${ }^{3}$ \\ ${ }^{1}$ Laboratoire de Géosciences Appliquées à l'Ingénierie de l'Aménagement, Faculty of Sciences, \\ Hassan II University, Casablanca, Morocco \\ ${ }^{2}$ GEOBIO Laboratory, Geophysics, Natural Patrimony and Green Chemistry Research Centre (GEOPAC), \\ Scientific Institute, Mohammed V University in Rabat, Morocco \\ ${ }^{3}$ Université Clermont Auvergne, CNRS, IRD, OPGC, Laboratoire Magmas et Volcans, Clermont-Ferrand, \\ France
}

Manuscript received: June 30, 2018

Revised version: February 11, 2019

Amine A., El Amrani El Hassani Iz., Remmal T., El Kamel F., Van Wyk De Vries B., Boivin P., 2019. Geomorphological classification and landforms inventory of the Middle-Atlas volcanic Province (Morocco): Scientific value and educational potential. Quaestiones Geographicae 38(1), Bogucki Wydawnictwo Naukowe, Poznań, pp. 107-129. 10 figs, 3 tables.

ABSTRACT: Through the tabular morphology of northwestern part of the Middle-Atlas in Morocco, numerous uncovered monogenetic volcanoes arise structured of pyroclastic product layers and lava flows. Our fieldwork results witness a wide-ranging volcanic shape spectrum, as cones, maars, tuff-rings, and cone-maar mixes, generally associated with a later lava flow discharge that could develop many surfaces and appearances. There are withal sundry eruptive products such as pahoehoe lava, scoria, tuff, lapilli, peperites, base-surges, bombs, etc. This monogenetic volcanic field of practically $1000 \mathrm{~km}^{2}$ offers remarkable eruptive landforms, referred to as the largest, and the youngest volcanic field in Morocco, which consists of a large area within the Ifrane National Park. This fieldwork study provides a renewed volcanic geomorphological classification table and GIS data to be used by a wide public range for both educational and geo-touristic interest and access effectively to such a high-mountain natural museum. In the event that these volcanic structures were appropriately dealt with, the high educational scientific content and the notable touristic vocation would almost certainly create business openings and new financial wages for neighborhood populaces. This work focuses to share our outcomes and emphases the scientific value about the monogenetic volcanic field around the tabular Middle-Atlas in Morocco.

KEY WORDS: volcanic geomorphology, eruptive dynamic styles, volcanoes, lava flows, Middle-Atlas volcanic province Corresponding author: Abdelmounji Amine, abdelmounji@gmail.com

\section{Introduction}

From the middle Miocene to Quaternary, basaltic volcanism took place in whole volcanic centres of Morocco, making of the Middle-Atlas volcanic province (MAVP), the youngest, and the largest volcanic field of Morocco, which holds many types of eruptive landscapes and 


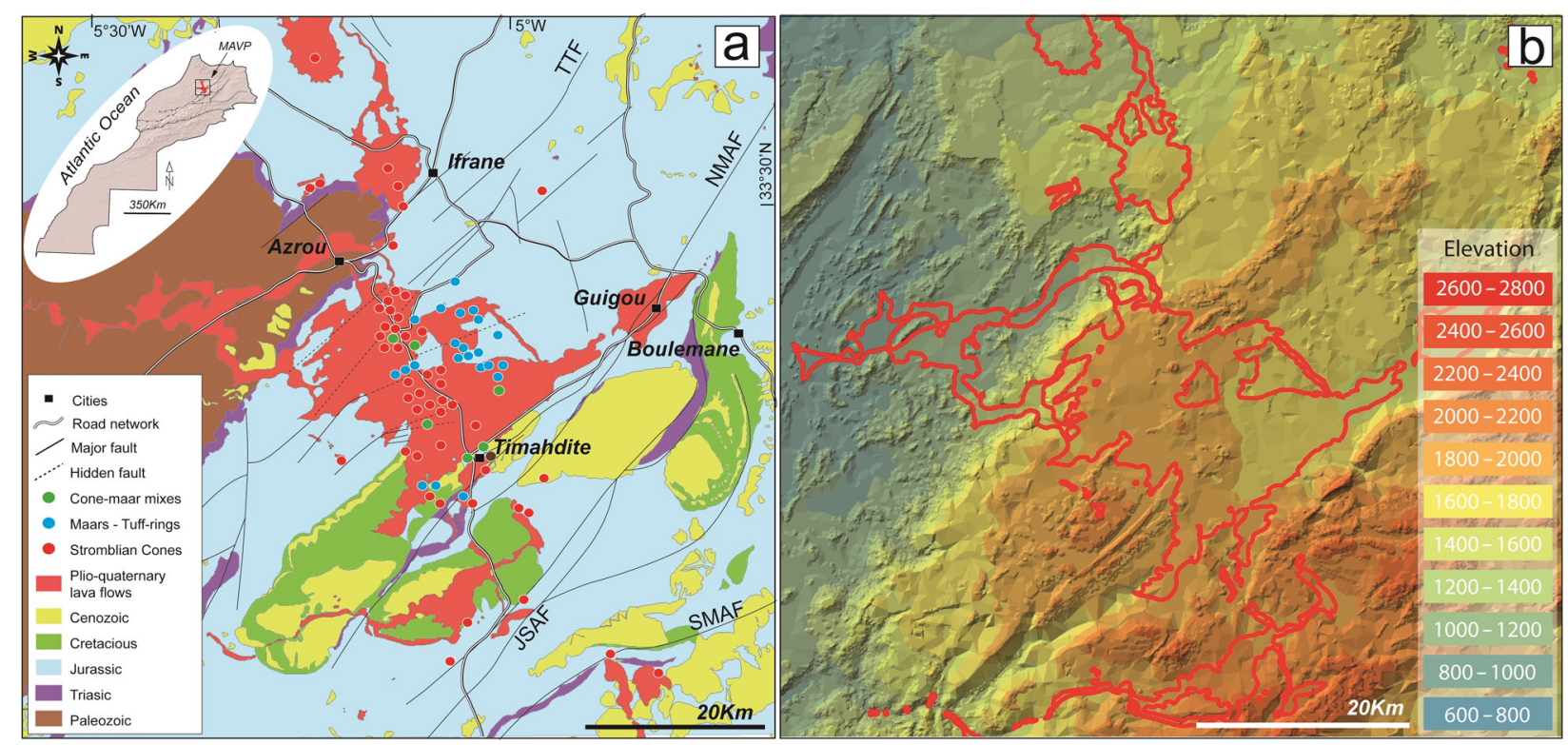

Fig. 1. Study area.

a) Geographical location and geological map of the study area. Most of volcanoes and lava flow units erupted from the Azrou-Timahdite plateau. These volcanoes strung along into two trails: the main cones dominated central trail and smaller eastern maars dominated trail that concentrates on the Azrou-Timahdite plateau.

Major faults abbreviation: TTF: Tizi-n-Tretten Fault; NMAF: North Middle-Atlas Fault; JSAF: Jbel Sidi Ali Fault; SMAF: South Middle-Atlas Fault. MAVP: Middle-Atlas volcanic province.

b) Coloured digital elevation model of the Middle-Atlas, showing the topographic framework of the study area. Heights are in metres above sea level.

deposits to fossilize a particular period in the geomorphological evolution of Middle-Atlas chain. Compared to other same-aged Moroccan volcanic provinces, it offers a varied morphostructural volcanic range of almost $1000 \mathrm{~km}^{2}$ (Fig. 1a). These include cones, maars, tuff-rings, cone-maar mixes, multiple cones, lava flows, lava tunnels, tumuli, Hornitos, and associated crypto-karsts (Martin 1981, Charriere 1984, Fedan 1989).

There are still doubts about the correct volcanic process and the environmental controls on the final morphostructural volcanic shape of these monogenetic volcanoes. Their short lifespan is intensely influenced by both internal and external environmental factors. Internal conditions are related to the chemical and physical properties of uprising magmas (e.g. chemical composition, temperature, viscosity, gas content, ascent rate, and magma flux) (Boivin et al. 1982, Parfitt, Wilson 1995, Neri et al. 1998, Németh, White 2003, Strong, Wolff 2003, Parfitt 2004, Giordano et al. 2010). External conditions are primarily controlled by the environmental properties, as well as the structural, lithological and hydrogeological framework (Vries, Borgia 1996, Lagmay et al. 2000, Lorenz et al. 2003, Clarke et al. 2009,
Nemeth, White 2009, Martí et al. 2011, Kereszturi et al. 2011, Stárková et al. 2012, Kshirsagar et al. 2016, Paguican, Bursik 2016).

These factors are together responsible for the dominant eruptive dynamic style and the expected fluctuations in a short time-scale, which is familiar with monogenetic volcanism (Clarke et al. 2005, 2009, Brand, Clarke 2009, Martí et al. 2011). The widespread of the shallow rich-water limestone aquifer in the tabular Middle-Atlas is an important aspect that generated some explosive eruptive centres, especially when precipitation and temperature oscillated persuading more complex volcanic geomorphology (Boivin et al. 1982, Traglia et al. 2009, Kshirsagar et al. 2016). Therefore, these phreatomagmatic and mixed eruptive centres play a crucial role as good sensors of the environmental variation (Wood 1980, Siebe 1986, Németh et al. 2001), mostly when superficial and ground water-table level changed (Lorenz 1984, Büchel 1993, Büchel et al. 2000).

In this work, we will concentrate on the volcanic geomorphological typology of the eruptive landforms through a well-illustrated volcanic features inventory, presented with simple and concise explanations of each volcanic process 
and landforms. These geosites of a great diversity constitute a true geo-heritage that needs more protection and treasuring (Malaki 2006, De Waele et al. 2008, El Wartiti et al. 2009). This study was established to share the scientific culture and emphases the volcanic geomorphological heritage of this area that promotes educational and geotouristic possibilities and new attraction centre for both national and international tourists.

\section{Geologic and geomorphologic setting of the study area}

The Middle-Atlas chain is a NE-SW $200 \mathrm{~km}$ elongated belt, organized into two structural units separated by the North Middle-Atlas Fault (NMAF) (Fig. 1a) (Martin 1981, Fedan 1989). The northwest tabular Middle-Atlas part consists of Jurassic and Cretaceous karstified limestone plateau with elevations ranging from 1400 to 2100 m (Fig. 1b), covered extensively by Quaternary basaltic floods and punctuated by Neogene monogenetic volcanoes. While the southeast folded Middle-Atlas part, with greater elevation (900-3300 m) is organized around four NE-SW oriented anticlinal ridges associated to major faults as NMAF and JSAF, bounding individualized sub-basins of folded Cretaceous and tertiary formations (Fig. 1a) (Charriere 1984, Fedan 1989, El Arabi et al. 2001). Most of volcanic units cover the flat karstic surface of a tabular Jurassic dolomitic limestone plateau, and seem to be continuous in the central part of the chain between Azrou and Timahdite, where clustered cones and maars erupted large lava units which forms the main volcanic axis (Martin 1981, Harmand, Cantagrel 1984). The MAVP includes nearly one hundred well-preserved cones and maars, which strung along a $\mathrm{N} 170^{\circ}$ directed trend for more than $70 \mathrm{~km}$ (Martin 1981, El Azzouzi et al. 2010). The distribution pattern of the monogenetic volcanoes of MAVP is nearly arranged along a major meridional lineament traversed of several N50-70 minor secondary lineaments (dotted line in Fig. 1) (Harmand, Moukadiri 1986, El Azzouzi 2002).

These volcanoes have emitted numerous low-silica lava flows covering a global surface of ca. $960 \mathrm{~km}^{2}$, but the esteemed volume remains relatively low $\left(20 \mathrm{~km}^{3}\right)$ because of the limited

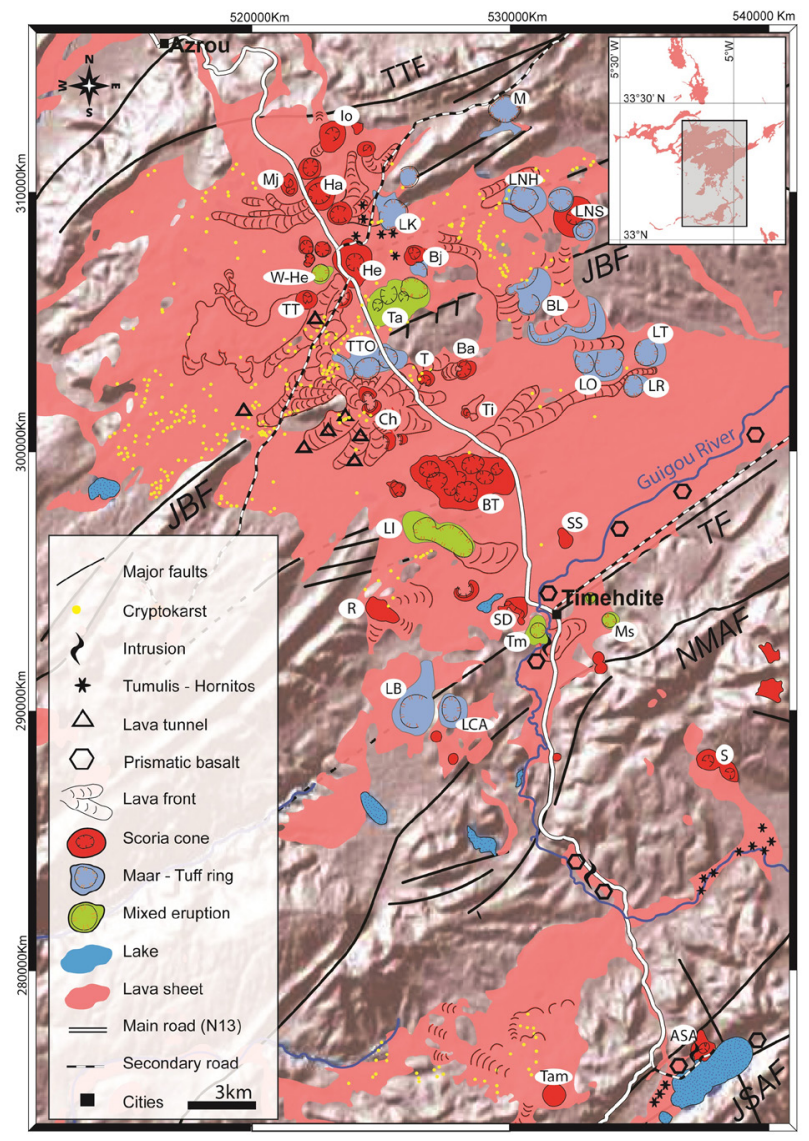

Fig. 2. Map of the main volcanic features on both tabular and folded domain of the central MiddleAtlas domain.

Volcanic device abbreviations: AK - Ain Kahla, Ba Bou Ahsine, Bj - Boutjatiout, BL - Boulbalrhatène, BT - Boutaguarouine, Ch - Chedifate, Ha - Habri, He - Hebri, Io - Ich Ouarrok, LB - LechmineBou Itguel, LBS - Lechmine Ben Said, LCA - Lechmine Chker Allah, LI - Lechmine Izgarn, LK - Lechmine-n-Kettane maar, NHL - Lechmine-Naït-Lhaj maar, LO - Lechmine Ouannou, LR - Lechmine N Rhelline, LT - Lechmine Tajine, M - Michlifène, Mj - Mijmouane, Ms - Msaarab south, RA - Rabouba, S - Selrhert, SA - Sidi Ali, SD - Sidi Boundouh, SS - Sidi Said, T - Taissaouit, Ta - Tahabrit, Tam - Tamarakoit, Ti - Tichinouine, Tim - Timahdite, TT - Tichout Tazouggaght, TTO - Touna-Tit Ougmar, W-He - West Hebri.

Fault name abbreviations: TTF - Tizi-n-Tretten Fault, JBF - Jbel Irhoud-Boulbalrhatene Fault, TF - Timahdite, NMAF - North Middle-Atlas Fault, JSAF - Jbel Sidi Ali Fault.

thickness average (20-30 m) of the lava flow pile (El Azzouzi et al. 2010). Strombolian cones occur within the entire volcanic area. However, maars (blue points in Fig. 1a) seem focused around the central part of the main volcanic axis (dominated by red points in Fig. 1a), especially on the east side between Azrou and Timahdite. 
These different types of volcanic activity cannot be related to a geodynamic regime temporal transformation. Compressive tectonics has been maintained all along the MAVP building period; they are correlated then to the presence of water or not in the setting environment. Around this area, Strombolian cones show a slightly higher elevation, but phreatomagmatic centres are generally located in a lower eastward area, which can be much closer to the shallow water table. The widespread karstic-carbonate rock layers combined to heavy precipitations as rain and as snow, make of the tabular Middle-Atlas an abundant groundwater sources (Amraoui 2004, Martin 1981, Miche et al. 2018), regarded as a great water tower and hydrological regulator in Morocco (Bentayeb, Leclerc 1977, Peyron 1980, Menjour et al. 2017). Generally, the Strombolian dynamic activity is dominant consisting of $66 \%$ of volcanic events. However, the presence of a fractured water-rich carbonate aquifer is suggested to be responsible for several explosive phreatomagmatic interactions with uprising magmas, which represents $26 \%$ of the features. Only $8 \%$ of volcanic devices tend to show a mixed eruptive morphology and witness the shifting between wet and dry dynamic style during the same shortlived monogenic eruption, which may represent good sensors of local environmental changes.

\section{Methods}

Our approach is built on numerous fieldworks around the volcanic area of the Middle-Atlas chain based on different investigations to recognize and map all inspected volcanic structures to suggest a renewed volcanic geomorphological typology, inspired from previous geomorphological classifications of different authors (Wohletz, Sheridan 1983, Boivin et al. 2004, 2009, Kereszturi, Németh 2012, Nemeth 2012), which takes into account eruptive styles, deposit stratigraphy, and emplacement mechanisms at tuff rings with those at cones and mixes. We relied first on capitalization of earlier literature data onto various geologic features of the recent volcanism of the Middle-Atlas (Martin 1981, Harmand, Cantagrel 1984, Harmand, Moukadiri 1986, De Waele et al. 2005, Malaki 2006, El Wartiti et al. 2009, El Azzouzi et al. 2010), and checking it by satellite image analysis to reveal more eruptive outcrops. The second stage consisted of mapping this volcanic area, inspect all volcanic features, identify their eruptive dynamic styles, morphologies, and pyroclastic deposits by morphological and lithostratigraphical field examinations. All these noted volcanic features and products were recognized and classified into an assorted typology between a geomorphological classification of the MAVP conducted by (Martin 1981), and general genetic classification of monogenetic basaltic volcanoes (Kereszturi, Németh 2012). As a final point, we arranged all fieldwork data into a synthetic table and schemes in GIS environment to produce a new volcanic geomorphological map (from Azrou to Aguelmam Sidi Ali), which could identify easily the clustered landforms nearby the central part of the MAVP. We used colours to denote different type of volcanoes according to their eruptive dynamic activities, and simple symbols to describe different lava flow surfaces. This map could be a useful tool as an educational guide field for scientists, naturalists, and large public.

\section{Results: volcanic morphostrutural classification}

The MAVP differs from the other Moroccan provinces due to the existence of various volcanic features derived from Hawaiian, Strombolian and phreatomagmatic eruptive dynamic styles as well as the abundance of shallow and deep-water resources. The existing volcanic morphostructures can range into four major groups: Fluid lava flows related to effusive Hawaiian activity; Cones related to dry Strombolian activity; Maars and/or tuffs rings related to wet phreatomagmatic activity, and Cone-maar mixes related to the shifting between dry and wet eruptive activities. For each eruptive group, we define the main eruptive morphology and products as follows (Table 1, 2, 3):

\section{Lava flows}

Lava flows cover about $20 \%$ of the tabular Middle-Atlas area (Figs 1, 2). Lava units overflowing from the volcanic main axis were channeled eastward into Guigou valley, and westward over 
Oued Beht and Oum Rbia valley, and northward over the Liassic substrate slopes. Because of the tabular topography and the alkaline magmatic tendency, these fluid lavas flowed easily over very long distances. For example, Tamarakoit volcano emitted a huge lava flow that tracked the Oued Oum Errabi valley over more than $100 \mathrm{~km}$. Morphologically, they have been able to petrify some volcanic structures from slow to rapid advancing and cooling, swelling and sinking, which is often spectacular.

\section{Lava Flows Surfaces}

Pahoehoe surfaces

Most of the overflowing lava cover units are pahoehoe with a smooth ropey and vesicular surface (Fig. 3a). They reflect hot and fluid lava flowing and slow flow-front velocities (Vergniolle, Brandeis 1996, Bardintzeff 2011, Taddeucci et al.
2015). The advancing pahoehoe front consists of a fluid core with an outer crust, comprising hundreds or thousands of individual active lobes referred to as toes (Fig. 3g).

\section{aa surfaces}

The second type of lava units is characterized by very rough breccia surfaces with a dense core, referring to aa lava flows (Fig. 3b) (Applegarth et al. 2010). They result from progressive chilling of a moving lava front, topped by rolling blocks of consolidated lava, chilled at the margins but still liquid in the core.

The transition from pahoehoe to aa lava-type along a single eruption has been recognized at the north-western flank of Taissout cone. A large pahoehoe lava flow covers the entire north-western slope, turning into a small tongue-like flow front with the angular blocky upper surface

Table 1. Classification table of cones according to their eruptive landform, height, width, elongation index, and the geographic location.

\begin{tabular}{|c|c|c|c|c|c|}
\hline Name & Eruptive landform & Height (m) & Width (m) & $\begin{array}{c}\text { Elongation } \\
\text { index }\end{array}$ & Location (WGS) \\
\hline Tabourit & \multirow[t]{15}{*}{ craterless } & 200 & $1100-2000$ & 1.81 & $33.181090,-5.251647$ \\
\hline Bekrite & & 120 & $1400-1500$ & 1.07 & $33.064061,-5.241821$ \\
\hline Outgui & & 120 & $1000-1200$ & 1.20 & $33.644252,-5.246676$ \\
\hline Si Mghid & & 100 & $450-550$ & 1.22 & $33.196662,-5.260765$ \\
\hline El koudiat & & 90 & $1100-1200$ & 1.09 & $33.531257,-5.156566$ \\
\hline Ariana & & 80 & $700-1000$ & 1.42 & $33.519565,-5.242534$ \\
\hline Ain Kahla & & 78 & $400-500$ & 1.25 & $33.229431,-5.218468$ \\
\hline Rabouba & & 72 & $450-500$ & 1.11 & $33.240984,-5.132338$ \\
\hline Tichout Tazoug & & 70 & $650-700$ & 1.07 & $33.347645,-5.161858$ \\
\hline Tamarakoit & & 65 & $350-400$ & 1.14 & $33.061960,-5.066542$ \\
\hline Sidi Said & & 63 & $450-800$ & 1.77 & $33.262311,-5.053953$ \\
\hline Tamahrart & & 60 & $600-700$ & 1.16 & $33.512481,-5.252448$ \\
\hline Lougnina & & 60 & $1000-1100$ & 1.10 & $33.011541,-4.832307$ \\
\hline Talsast & & 60 & $600-700$ & 1.16 & $33.229551,-5.276386$ \\
\hline Mijmouane & & 33 & $450-600$ & 1.33 & $33.387091,-5.167786$ \\
\hline Jbel Hebri & \multirow[t]{4}{*}{ ring-shaped } & 220 & $1200-1300$ & 1.08 & $33.313252,-5.136189$ \\
\hline Am Larays & & 200 & $1000-1400$ & 1.40 & $33.034140,-4.890189$ \\
\hline Chédifate & & 167 & $2000-2500$ & 1.25 & $33.313252,-5.136189$ \\
\hline Sidi Ali & & 75 & $650-700$ & 1.07 & $33.313252,-5.136189$ \\
\hline Jbel Habri & \multirow[t]{9}{*}{ horseshoe-shaped } & 100 & $1200-1300$ & 1.08 & $33.385425,-5.154080$ \\
\hline Ouaouseenfacht & & 100 & $1200-1600$ & 1.33 & $33.596260,-4.686587$ \\
\hline Selrhert & & $70-90$ & $450-750$ & 1.66 & $33.178465,-4.995152$ \\
\hline Ich Ouarrok & & 85 & $1000-1300$ & 1.30 & $33.404557,-5.150691$ \\
\hline Bouahcine & & 65 & $750-800$ & 1.06 & $33.322261,-5.095985$ \\
\hline Boutjatiout & & 62 & $700-800$ & 1.14 & $33.309686,-5.091728$ \\
\hline Sidi Boundouh & & 60 & $900-1000$ & 1.11 & $33.239289,-5.075849$ \\
\hline Taissaouit & & 57 & $750-800$ & 1.06 & $33.318892,-5.110387$ \\
\hline Tichinouine & & 45 & $450-1000$ & 2.22 & $33.309686,-5.091728$ \\
\hline Boutaguarouine & nested (8) & 155 & $2500-4000$ & - & $33.284479,-5.093798$ \\
\hline
\end{tabular}


Table 2. Classification table of maars associated to tuff-rings according to their eruptive landform, depth, crater's width, elongation index, and the geographic location.

\begin{tabular}{|c|c|c|c|c|c|}
\hline Name & Eruptive landform & Depth (m) & $\begin{array}{l}\text { Crater width } \\
(\mathrm{m})\end{array}$ & $\begin{array}{c}\text { Elongation } \\
\text { index }\end{array}$ & Location (WGS) \\
\hline Michlifène & \multirow[t]{4}{*}{ deep maar/tuff-ring } & 120 & 800 & 1.00 & $33.413500,-5.079369$ \\
\hline Lechmine N Ait Lhaj & & 110 & 850 & 1.00 & $33.382723,-5.070212$ \\
\hline Lechmine N Kettan & & $70-100$ & $1000-1100$ & 1.10 & $33.378136,-5.125830$ \\
\hline Lechmine Bou Itguel & & 90 & 1300 & 1.00 & $33.202695,-5.117515$ \\
\hline Lechmine N Rhelline & \multirow{4}{*}{$\begin{array}{c}\text { shallow maar/tuff- } \\
\text { ring }\end{array}$} & 40 & 650 & 1.00 & $33.315974,-5.024742$ \\
\hline Tafraout & & 30 & $800-1000$ & 1.25 & $33.522731,-4.691432$ \\
\hline Lechmine Tajine & & 30 & $800-1100$ & 1.35 & $33.327478,-5.019378$ \\
\hline Lechmine Chker Allah & & 30 & $700-800$ & 1.14 & $33.205212,-5.102474$ \\
\hline Tuna - Tit Ougmar & \multirow[t]{2}{*}{ maars complex } & $35-40$ & $500-900$ & - & $33.322102,-5.136088$ \\
\hline Boulbalrathene & & $20-50$ & $500-1200$ & - & $33.343615,-5.063990$ \\
\hline
\end{tabular}

Table 3. Classification table of eruptive mixes according to their eruptive landforms, elevation's difference, width, and the geographic location.

\begin{tabular}{|c|c|c|c|c|}
\hline Name & Eruptive landforms & Elevation difference & Width (m) & Location (WGS) \\
\hline West Hebri & cone $\rightarrow$ maar/tuff-ring & 65 & 800 & $33.357214,-5.151767$ \\
\hline Msaarab Sud & \multirow{3}{*}{ maar/tuff-ring $\rightarrow$ cone } & 75 & 500 & $33.234592,-5.037232$ \\
\hline Lechmine Izgarn & & 200 & $400-2500$ & $33.264304,-5.105774$ \\
\hline Timahdite & & 100 & $800-1100$ & $33.230974,-5.066730$ \\
\hline Tahabrit & maar/tuff-ring $\rightarrow$ nested cones (3) & 180 & 2600 & $33.347028,-5.127267$ \\
\hline
\end{tabular}

at the base of the volcano. This morphological transition is commonly recognized as irreversible (Hon et al. 2003), controlled by viscosity and strain rate properties (Peterson, Tilling 1980).

\section{Columnar Jointed Basaltic Lavas}

The widespread several metres thick fluid lava floods allow a wide interface of contact with the cool ground, which leads to columnar jointed structure formation with parallel sides and diameters of few decimetres in relatively thick lava bodies. The column forms are a typical result of slow upward cooling from the base and rapid downward cooling from the top (Spry 1962, Goehring, Morris 2008, Boivin 2017). With increasing lava flow thickness, the top and bottom of the flow are vesicular and fractured, but the central part turns into dense and less vesicular disorderly hexagonal prisms (Fig. 3c). The best hexagonal-shaped column's outcrops occur along Guigou river valley around Timahdite and Aghbalou Abarchan and in lava flows surrounding Aguelam Sidi Ali Lake (Fig. 2). They occur along hydrographic network depressions.

\section{Protrusions and Plugs}

They form when magma intrudes into a crack and then usually crystallizes under high-angle to near vertical in orientation. The hot liquid is injected outward when fissures and tectonic cracks open giving rise to protrusions and plugs of different dimensions. The upper surface of the moving lava flow unit may be rugged due to the emergence of many veins from the inside. These veins form perpendicular to the main flow direction, by the advancing fluid core under a chilled and cracked margin. Well-exposed features occur in Aghbalou Abarchan lava flow and around Timahdite and Aguelmame Sidi Ali volcanoes (Fig. 2d).

\section{Lava Tunnels}

During a fluid lava flowing, the edges cool faster than the core and can form some isothermal tunnels that channel forward the super-heated magma. Later, lava can abandon its solid shell and leave a wide open cylindrical tube with an elliptical cross-section up to several kilometres long (Dragoni et al. 1995, Dragoni, Santini 2007, Bardintzeff 2011, de Silva, Lindsay 2015). After discharging, the roofs of these tunnels may collapse to uncover their existence. Through the MAVP, lava caves are associated only with the most effusive and mafic volcanic vents (Fig. 2). They occur west of Tit-Ougmar complex maar where a released entrance illustrates the Ifri 

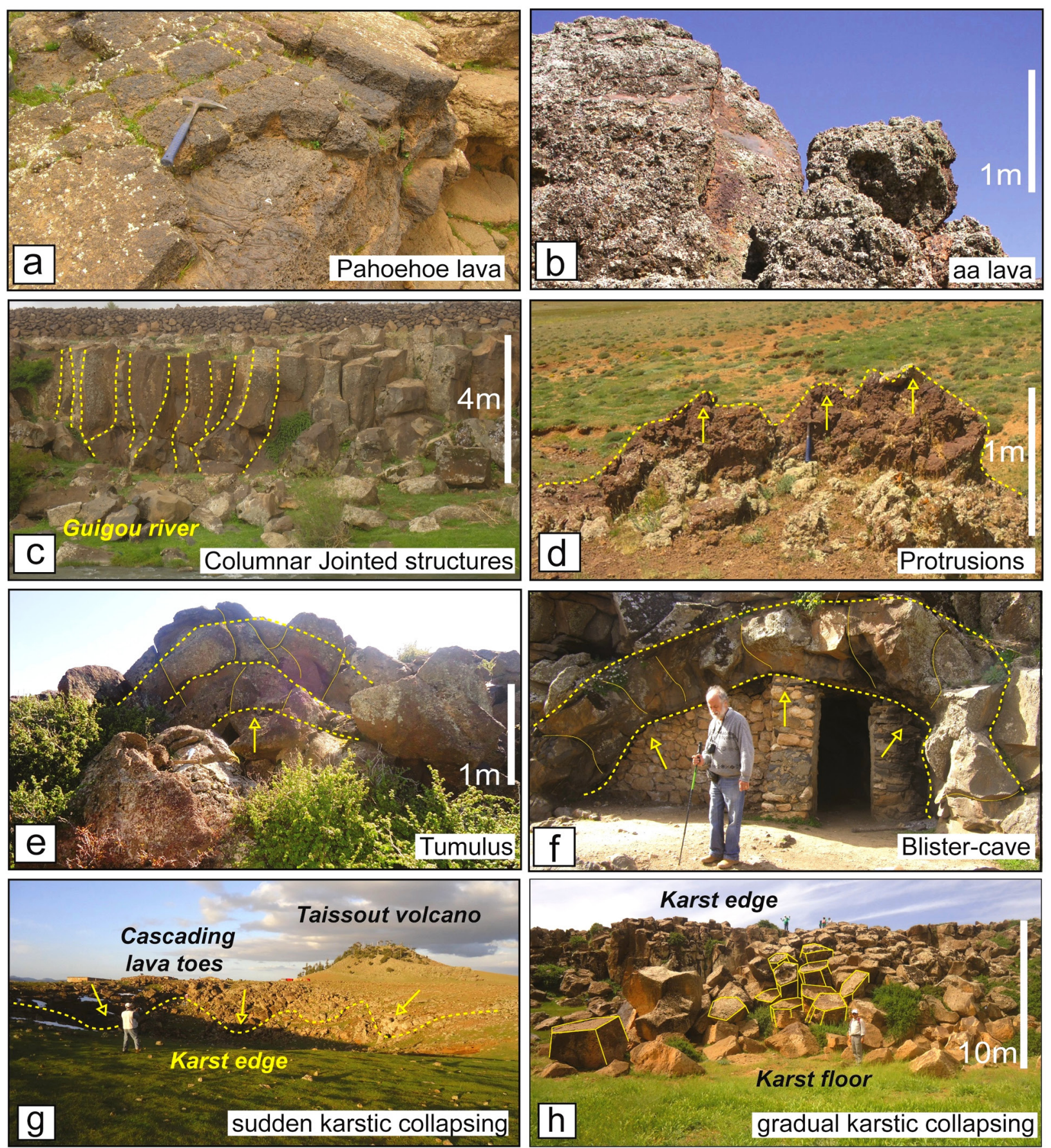

Fig. 3. Main eruptive landforms and structures of lava flow units.

a) The smooth degassed surface of fluid pahoehoe lava near the Taïssaouite volcano.

b) The rough scoriaceous aa surface of viscous lava tongue emitted from the base of the Taissousit volcano.

c) Columnar jointed structure outcrops beside Oued Guigou on the south-eastern side of the Timahdite volcano.

d) Fluid uprising lava intrusion emerging from an opened crack at the Aguelmam Sidi Ali volcano edge.

e) Tumulus structure west of the Aguelmam Sidi Ali volcano.

f) Blister-Cave that formed below the advancing Aghbalou Abarchan lava unit, which has about $5 \mathrm{~m}$ in width and $2 \mathrm{~m}$ in height.

g) Photo of an advancing pahoehoe lava toes that cascade over karstic slopes simultaneously with a sudden collapsing near the north-western Taissout volcano; there are superb folded and wrinkled lava screes covering the karstic floor.

h) Photo of a steady karstic collapsing at the eastern edge to Aguelmame Sidi Ali Lake; the inward tilting of the columnar basalt on the inner slope result from a long but continuous carbonate dissolution subsidence. 
Ouska tunnel, highlighted by a late roof collapsing. They occur also at the southwest flank of the radiating lava Chedifate volcano characterized by several aligned cave entrances of at least two large lava flows.

\section{Tumulus - Hornitos}

These structures are positive elliptical topographic features of several metres in height, with no apparent crustal shortening, set on the gentle slopes of pahoehoe flows (Walker 1991, Anderson et al. 2012, Diniega, Németh 2014). They represent a slow-moving lava injection underneath the partially frozen scab, which is dragged upwards. However, it could also be induced by a deviation due to an irregularity in the underlying topography which causes an upward flow (Kilburn 2004). In the MAVP, we identified many examples around volcanoes generating a huge amount of lava as, Jbel Hebri and Aguelmam Sidi Ali flow (Fig. 3e). These conic structures form gradually on lava flow surfaces where the crust opens as well as gas and lava blow up under pressure, generating a rootless small spatter-cone in the lava field which is a few tens of metres high and wide (Németh et al. 2008, Ort et al. 2008, Diniega, Németh 2014). Several hornitos are located on the southern side of the Lechmine-n-Kettane maar. However, in the water-rich environment as Aguelamame Sidi Ali and Selrherte depression, there are many features as described, then seem to have an elevated and cracked roof under pressure without any ejected lava. Then, the vertical outcrop of the Imin Khnig lava flow offers a well-exposed blister-cave of two metres in height and five metres across (Fig. 3f). This structure is formed due to the progressive evaporation of the alluvial water at the base of the flowing lava unit to form an upward pushing blister structure.

\section{Volcano-karstic Collapsing Cavities}

About 300 collapsing cavities (Fig. 3), showing generally subcylindrical sections of few tens of metres in diameter and 5 to 40 metres deep puncture most of the lava flow surfaces. They have collapsed under a combined effect of the pronounced lava flows weight and permeability, and the removal of underlying cavities under the limestone dissolution process (Martin 1981). Most of cryptokarstic structures seems to share the same regional faulting system as volcanoes but some ones may confuse with some existing lava tunnels. The cryptokarstic collapsing remains the result of a sudden or gradual subsidence by corroding the underlying karst galleries.

\section{Sudden collapsing cavities}

They form when fluid lava flows cascade the slopes of a freshly formed collapsing, possibly due to the pronounced lava weight. The northwest side of the Taissout volcano offers the perfect example. The asymmetric depression is a few tens of metres across, and a few metres deep. The western slope is gentle, while the eastern slope is steep-sided and dominated by large folded and fallen lava screes recording wrinkled structures when lava cascaded downwards (Fig. 3g).

\section{Gradual collapsing cavities}

The collapse occurs after the lava flow spreading and cooling more frequently. The cryptokarst bottom consists of unstable columnar jointed fallen lava blocks, indicating an active subsidence after the complete lava flow cooling. Great examples of this cryptokarst type appear on the north-western side of Tit Ougmar maar, at the south-western side of Jbel Hebri, on the Aïn Kahla trail near Ifri or Berrid caves, and on the eastern side of Aguelmane Sidi Ali Lake (Fig. 3h).

\section{Cones and related products}

Cones represent the dominant volcanic shape of about $66 \%$ of volcanoes. Most of them strung along a sub meridian orientation alongside the national roadway no. 21 (NR21) between Azrou and Timahdite for nearly $30 \mathrm{~km}$ (Fig. 2) (Tab. 1). They are up to $200 \mathrm{~m}$ in height of a diameter between 500 and $2000 \mathrm{~m}$. In general, cones are related to Strombolian eruptive dynamics consisting of alternative explosion series of upraised large gas bubbles breaking at the surface of the magmatic pipe, throwing all-sized lava packets into the air (Vergniolle, Brandeis 1996, Houghton, Gonnermann 2008). Bedding may consist of thickly-bedded and poorly-indurated alternating of coarser and finer fall layers deposited at slope angles up to 30 degrees. The Strombolian eruption deposits are categorized by the existence of many bombs of different shapes and sizes, named according to their shape, which is controlled by magmatic fluidity and cooling conditions of the 
projected magma. Here, we described four cone types according to their shape, size, and the presence or absence of a crater.

\section{Craterless cones}

These are reddish cones of a few tens of metres in height, a build-up of scoria, bombs and partly solidified lava spatters. They are related to the eruption of hot, fluid basaltic lava fountain, whose ballistic ejectas land in a plastic state and agglutinate to form regular cones of steep slopes (Head III, Wilson 1989, Sumner 1998, Sumner et al. 2005, Carracedo Sánchez et al. 2012). Morphological observations indicate that towards the end of this eruption type, lava might fill the crater and overflow on the lower flanks of the cone (Vespermann, Schmincke 2000). The craterless cones type present $50 \%$ within the most mafic low-silica cones. We designated these well-exposed and easy access volcanoes to present this cone type, as Tichout Tazzouggart located $2 \mathrm{~km}$ southwest of Jbel Hebri (Fig. 4a), Sidi Saïd volcano located $3 \mathrm{~km}$ northward of Timahdite, and Mijmouane located west of Jbel Habri.

\section{Ring-shaped cones}

These cones correspond to circular or slightly elliptical plans, closed craters, and mostly symmetrical cross-sections. These are wide diameter cones up to $200 \mathrm{~m}$ in height, with a bowl-shaped crater at the top, commonly filled of reworked pyroclastic debris and lava flow blocks. They range from reddish to greyish and consist of scoria and bomb layers interstratified with continuous to discontinuous levels of fluid lava spatters. Eruption generates a perfectly regular cone with no external influences. This perfect ring-shaped cone's type presents only $14 \%$ of cones. The best examples from the main volcanic axis are Jbel Hebri (Fig. 4b) and Chedifate located beside the NR21, and from MAVP periphery are Aguelmam Sidi Ali and Am Larays.

\section{Horseshoe-shaped cones}

These volcanoes show an open main crater and the absence of part of their flanks, which can be due either to the lack of construction or their truncation by subsequent emissions of lava flows. The topographical effect and the wind could be factors that condition the final shape.
The breaching of cone relates to several factors, such as wind, the substrate tilting, the alternation of explosive and effusive phases, and the geometry and orientation of feeder dyke (Dóniz-Páez et al. 2008, Bemis et al. 2011, Kereszturi, Németh 2012, Rodriguez-Gonzalez et al. 2012). Jbel Habri and Boutjatiout volcanoes exhibit the largest Horseshoe-shaped cone occurrences (Fig. 4c).

\section{Multiple cones}

They are multiple volcanoes constructed due to the association of several cones of different sizes, resulting from simultaneous and juxtaposed eruptions of more than one volcano (Fig. 4d). This morphology indicates that their construction results from an eruptive fissure morphology depending on a combination of several factors, such as fissure, dynamic eruption or slope surface (Romero 1991, 1992). The Boutagrouine complex located $10 \mathrm{~km}$ northward of Timahdite shows eight nested cones arranged along two parallel $\mathrm{N} 70^{\circ}$ oriented faults. This complex was assembled during alternative eruptions throwing pyroclastic deposits outward and lava flows, enclosing thick layers of more or less vesiculated scoriaceous products that could be exploited for many industrial cases for their physicochemical properties.

Strombolian eruptive products:

- Spindle, Fusiform, or Rotational bombs: characterized by aerodynamic profile, due to the molten lava fragment rotation during its cooling ballistic trajectory (Fig. 5a). These bombs occur around the biggest cones as Jbel Hebri, Jbel Habri, Boutagrouine, and Aguelmam Sidi Ali.

- Cowpat bombs: formed by the flattening of a highly fluid magma fragment which partly solidified in the air before striking the ground. Their existence suggests that the outer surface chilled relatively quickly before the underlying vesicule's expansion, which became trapped and flattened beneath the chilled outer surface. These bombs occur in west Hebri maar, Aguelmam Sidi Ali, and Timahdite volcanoes.

- Bread-crust bombs: rapid chilling of a glassy surface during flight through the air forms a cracked cooled surface. The outer shell of the bomb cools when the hot gases inside contin- 
ue to expand and push apart the crust. The only example occurs around the pozzolan quarry west to Jbel Hebri (Fig. 5b).

Pozzolan quarry's deposits from Strombolian volcanoes such as Jbel Hebri, Boutagrouine, Timahdite, and Aguelman Sidi Ali, allow us to make clear observations on the eruptive dynamics with the spatial and temporal volcanic product's distribution. We can distinguish between the massive inner deposits from the core and the fine-grained outer facies from the periphery. The heaviest elements lands near the eruptive centre, while the lightest elements occur near the periphery:
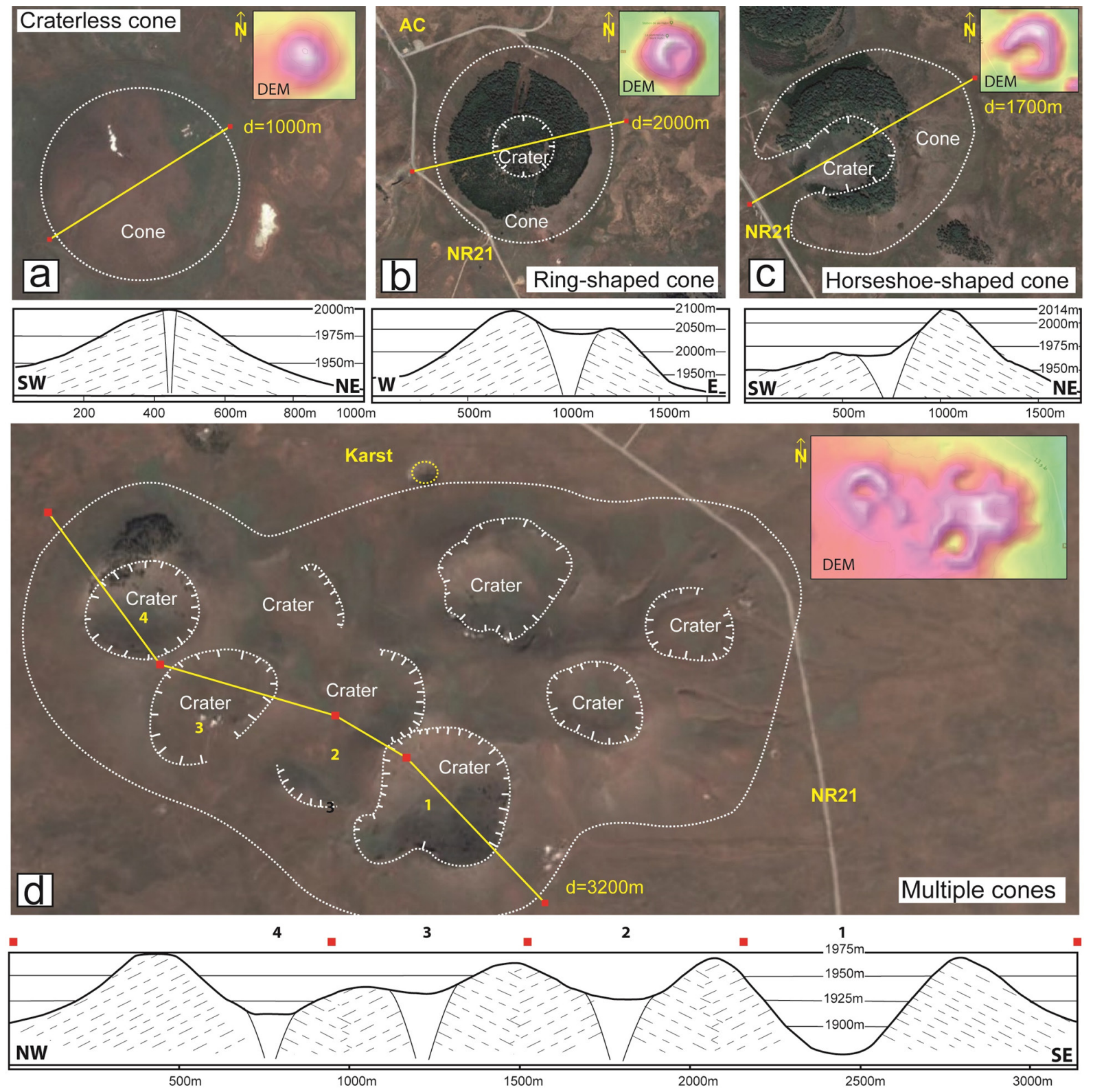

Fig. 4. Morphology, shape, and crater outlines of cones sketched on Google satellite images jointed to the digital elevation overview and the cross-section sketch. DEM - Digital Elevation Model; NR21 - national roadway no. 21.

a) Tizzout Tazouggart craterless cone.

b) Jbel Hebri cone with a bowl-shaped crater; the famous ski station occurs at the northern steep slope. AC: Accommodation centre.

c) Jbel Habri elongated horseshoe-shaped cone with an opened crater toward the national road.

d) The multiple cones of Boutagrouine are formed of eight volcanic devices arranged along NW-SE and NE-SW oriented lineaments; the Karst occurring in the northern slope may be stuck easily into the local pseudo quadratic tectonic network system. 

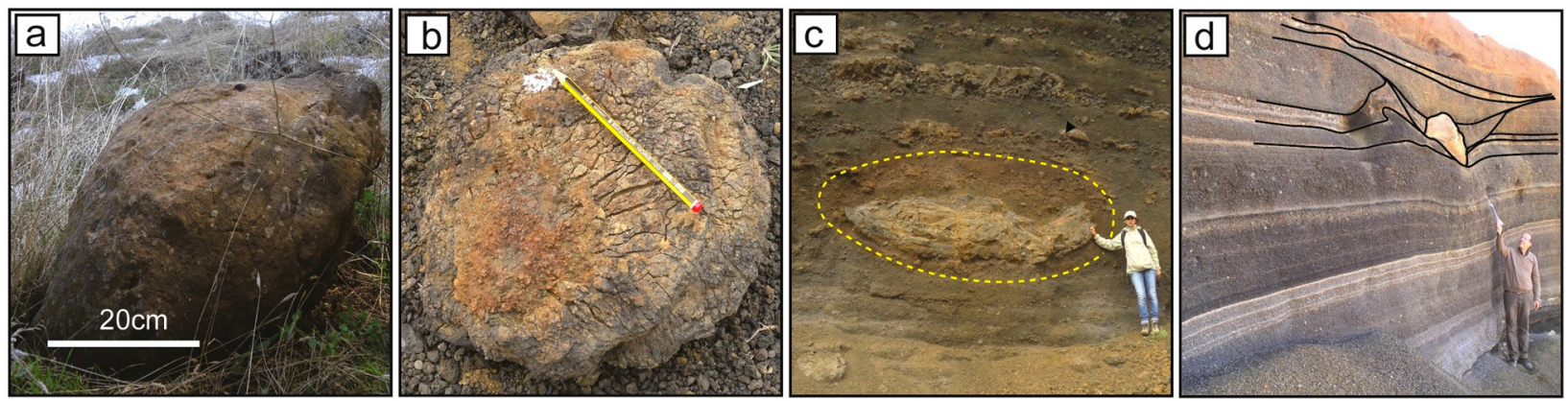

Fig. 5. Eruptive deposits from Strombolian cones.

a) Spindle-bomb occurring on the northern flank of Jbel Habri.

b) Bread-crust bomb occurring at the Strombolian base of west Hebri volcano.

c) Proximal reddish and coarse facies outcrops from the north-eastern quarry of the Timahdite volcano; the centre of the photo uncovers a large cowpat-bomb, developing an oxidation aureole over surrounding deposits.

d) Distal facies outcrops at the quarry on the eastern flank of Boutagrouine volcanic complex; interstratified ash levels attested the coexistence of both Strombolian and phreatomagmatic dynamics during the eruption.

- Proximal deposits: Chaotic, poorly sorted and red coloured. They consist of vesiculated lapilli, scoriaceous blocks, large bombs and spatters of massive lava. The partly melted fragments have agglutinated and welded aspect retaining their individual forms. Their reddish tint is due to the high temperature of the pyroclasts at landing which induces their oxidation in contact with the air. Example from pozzolan quarry from Timahdite shows the best illustration (Fig. 5c).

- Distal deposits: Fine-grained particle size, moderately sorted and dark-coloured. The deposits are mainly ash and lapilli combined with a few relatively small bombs, which are sufficiently cooled on landing to stay unchanged. There are also accumulations of large blocks on the lower slopes of cones, which have rolled from the summit area after their fall. Outcrops from Boutagrouine quarry offer a clear observation of the fine-bedded distal deposits (Fig. 5d).

\section{Maars/Tuff-rings and related pyroclastic deposits}

These volcanic structures represent about $26 \%$ of volcanoes. Majority of them concentrate on the east of the main volcanic alignment (Fig. 2) (Tab. 2 ). These maars are formed during phreatomagmatic eruptions under explosive interactions between ascending magma and water. The plume generated by this type of eruption is composed essentially of vaporized water, lava intensely fragmented, ash, lapilli, bombs, and bedrock breccia that were thrown outward. The central depression is surrounded entirely or partly by a thinly-bedded, poorly-indurated, polylithological pyroclastic tuff-ring with bedding angles of less than 12 degrees. Maars from MAVP show nearly the same morphology, but each flank may retain its own characteristics. In contrast to some elongated shapes, maars generally have a subcircular form of 400 to $1200 \mathrm{~m}$ diameters, and 20 to more than $100 \mathrm{~m}$ deep. We gave more attention to these maars from MAVP because they are grouped in a limited area and represent the geomorphological particularity regarding the other volcanic provinces. Through many fieldworks, we encountered some volcanic centres formed when several maars erupted at once. Then, we could range maars/tuff-rings as simple or multiple with a more or less deep crater.

\section{Simple deep maars}

Lechmine-Naït-Lhaj maar

The maar is about $850 \mathrm{~m}$ in diameter and $110 \mathrm{~m}$ deep. The lower $30 \mathrm{~m}$ is cut into the Liassic limestone substrate, overlain by a pyroclastic tuff-ring rich in limestone lithics. The lower part of the tuffring has layers of almost $40 \mathrm{~m}$ thick. The south and west side of the crater is covered with lava flows that cascaded in before the end of the phreatomagmatic activity. Towards the summit, the phreatomagmatic tuff is covered by a semicircular ring of scoriaceous and blocky juvenile deposits, built up by phreatomagmatic fragmentation of the incoming lava flow (Mountaj et al. 2014). These deposits can be traced to a quarry $500 \mathrm{~m}$ eastwards, where fine-bedded scoriaceous lapilli 
deposits are extracted. This maar shares the same orientation trend of $\mathrm{N}^{\circ} 0^{\circ}$ as the surrounding dolines and sinkholes, indicating a common structural relationship; possibly the magma exploited the karst system to reach the surface (Fig. 6a).

\section{Single shallow maars}

\section{Lechmine Cheker Lah maar}

This maar of subcircular shape is about 1000 $\mathrm{m}$ in diameter and $30 \mathrm{~m}$ deep (Fig. 6b). This depression is located at the north-western cliff of the Timahdite syncline, taking part of volcanoes that line the North-Middle-Atlas fault. Because of the ascending magma interaction with a shallow aquifer, the maar did not sink deeply as the Lechmine Nait l'Haj case. During the eruptive activity, phreatomagmatic explosions which occur in the crater have propelled outward all-sized lava fragments and limestone breccias to define a finely-bedded bordering tuff-ring around the crater. The eastern flank of the tuff-ring is exploited for the fine wind-driven pozzolan. Pyroclastic deposits of the Lechmine Bou-Itguel latter eruption partially cover the northern side of this maar.

\section{Complex maars:}

Tuna - Tit Ougmar Maar Complex

This maar complex was formed around three tuff-rings oriented along an $\mathrm{N} 70^{\circ}$ fault at the northern side of Chedifate volcano. The western tuff-ring shows an ellipsoid shape $(750 \times 500 \mathrm{~m})$ elongated along an NW-SE axis, and reaches more than $40 \mathrm{~m}$ in height (Fig. 6c). The northwest-slope absence is due to a simultaneous emission of lava during the tuff-ring build-up. This allowed lava flows to extend further towards the northeast and the southwest. The middle tuff-ring shows also an ellipsoidal form $(900 \times 750 \mathrm{~m})$ and has pyroclastic deposit layers of nearly $35 \mathrm{~m}$ thick. The main maar axis parallels the main $N 70^{\circ}$ fault. The circular eastern tuff-ring (called Tuna) is crosscut by the road. This relatively small vent is about $500 \mathrm{~m}$ across and $20 \mathrm{~m}$ deep. The northern slope exhibits fine-bedded phreatomagmatic breccias, while the southern slope is a wall composed of compact basalt.

\section{Phreatomagmatic eruptive products:}

- Base-Surge: Recognized as products of the most hazardous eruptive phase, originating from a high-speed flow of gas and particulate mixture during the propagation of the phreatomagmatic eruption shock waves. These finely-bedded ash beds display high-energy sedimentary structures (dunes, anti-dunes, cross-stratifications), corresponding to the typical deposits of the first stage phreatomagmatic explosion (Fisher, Waters 1970, Schmincke et al. 1973, Fisher 1977, 1979, Chough, Sohn 1990, Wohletz 1998). This typical pyroclastic formation appears only at the base of Timahdite volcano indicating the prevalence of shock-wave explosions when the eruption started (Fig. 7a).

- Peperit layers: This is a generic term applied to a rock formed essentially by near-surface disintegration and active mixing of ascending magma and wet country rock. Mingling accompanies fragmentation because of the heat transfer from hot magma in contact with the surrounding water. The peperit formation is assisted by hot interstitial water in sediments, which produces a steam matrix allowing the sediment to act fluidly (Batiza, White 2000). Peperite beds show a muddy and granular aspect of a polylithological micro-breccia, consisting of blocky lava fragments, polyhedral lapilli, glassy shards and accidental lithics enclosed in an ashy matrix (Hooten, Ort 2002, Skilling et al. 2002). Occasionally, peperit may contain armoured lapilli like pepper grains, formed by accretion of ashy envelopes during a turbulent overheated and condensed gas-supported transport (Schumacher, Schmincke 1995). Outcrops from Lechmine-Naït-Lhaj maar, Timahdite, and northern Msaarab expose the thickest peperit layers (Fig. $7 \mathrm{~b}$ ).

- Stone Sun's structures: Some base-surge and phreatomagmatic tuff associations show radial jointing cracks extending from wet clast rims into the ashy matrix, as described by (Skacelova et al. 2010) in phreatomagmatic breccia's beds at Hnojnice volcano, in the Czech Republic. The only feature of these structures occurs at the north-western base of the Timahdite volcano (Fig. 7c).

- Bomb-sag: A deformation of unconsolidated pyroclastic tuff bed structures by the ballistic impact of a large block and bomb, emitted from the vent during violent explosive activity (Clarke et al. 2005, 2009). The asymmetry of the deformation structure traces the vent 
location. The north-eastern base of the Timahdite volcano reveals those bedding structures of wet and plastic response to the ballistic impact (Fig. 7d).

- Cauliflower-shaped bombs: they have a dense to vesicular interior with rough cauliflower appearance results from ballistic impact and rapid quenching in wet environments causing a sudden and unequal distortion (Lorenz 1973, Rosseel et al. 2006). If the heat flux is sufficiently high, the bombs could weld with the underlying deposits. The widest cauliflower
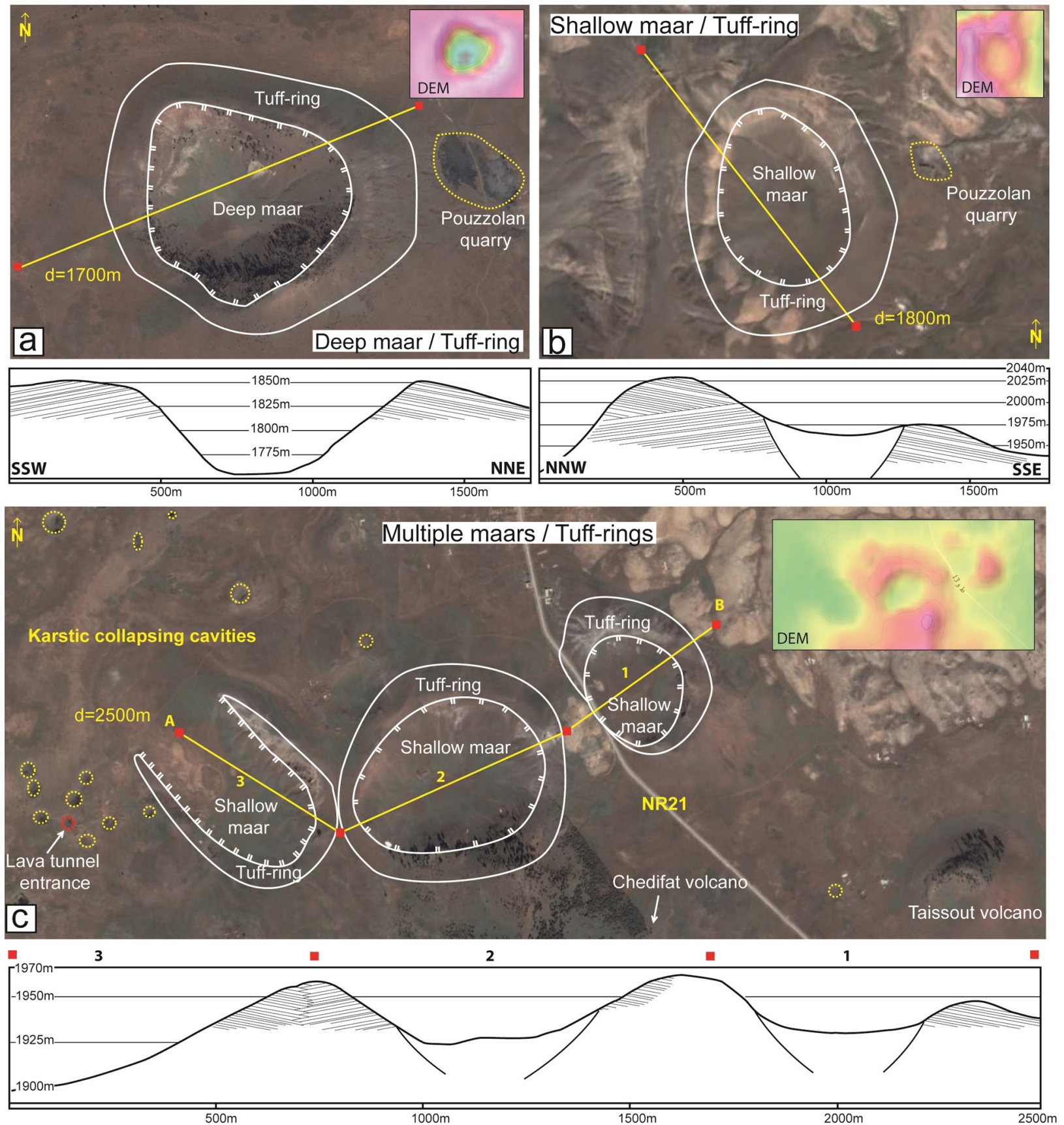

Fig. 6. Morphology, shape, and crater outlines of maars surrounded by tuff-rings sketched on Google satellite images jointed to the digital elevation overview and the cross-section sketch. DEM - Digital Elevation Model;

NR21 - national roadway no. 21.

a) Deep maar of Lechmine N'ait 1 Haj.

b) The elongated shallow maar of Cheker Allah.

c) The Touna (eastern maar) - Tit Ougmar (central and western maar) complex. Many karstic cavities occur west of this volcanic complex and overlay some local tectonic lineament. 

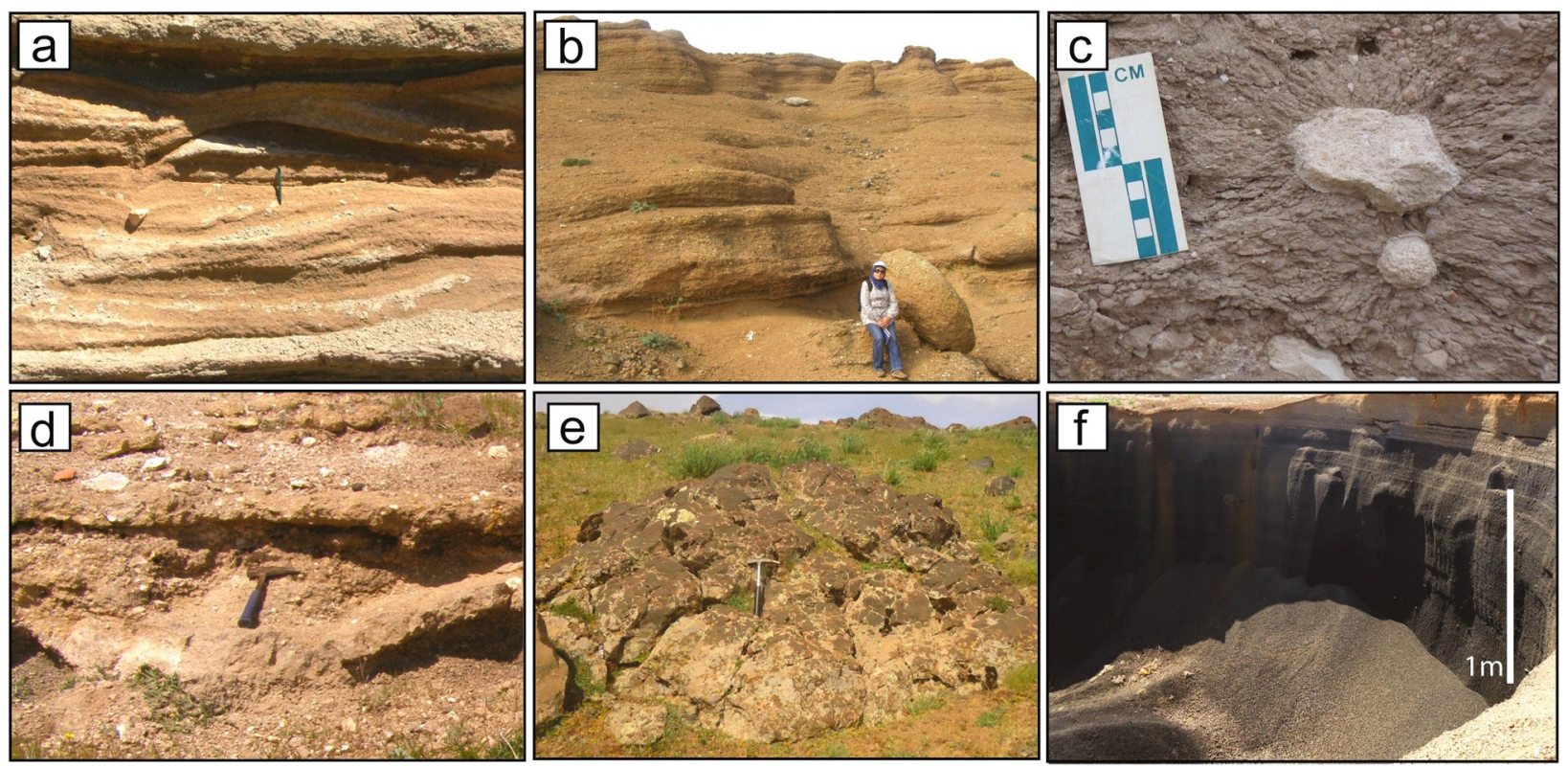

Fig. 7. Phreatomagmatic eruptive products

a) Southern base-surge outcrop from the Timahdite volcano showing a small-scale dune and anti-dune sedimentary figures including some lapilli lenses.

b) Thick peperite layers from the phreatomagmatic deposits exposed in the Lechmine-Naït-Lhaj maar northern flank; they consist of alternating thick ash-dominated levels with coarser lapilli falls.

c) Stone suns structures exposed in phreatomagmatic deposits at the north-western base of the Timahdite volcano.

d) Bomb-sag structure distorting the phreatomagmatic deposit bedding at the north-eastern side of the Timahdite volcano.

e) Cauliflower bomb of 1,5 m diameter occurs in the northern part of west Hebri Maar.

f) Finely-bedded lapilli fall is representing the distal wind-driven facies at the base slope of the eastern flank of Lechmine N'ait Lhaj maar.

bombs occur on the northern flank of the west Hebri volcano (Fig. 7e).

- Pozzolan: It can occur in distal zones and can be over several metres thick, over a well-defined bedding of fine-grained well-sorted deposits. The best-known example occurs at the base of the eastern flank of Lechmine-Naiit-Lhaj maar, which is the largest pozzolan quarry in the MAVP exploited by the cement manufacturers; it is also thrown on roads to stabilize car's tires during snowy conditions (Fig. 7f). Existence of significant pozzolan quantities in the edge of maars signifies progressively drier conditions or alternating wet phreatomagmatic and dry strombolian eruptions (Camus, Vincent 1973, Boivin, Gourgaud 1978, Houghton, Schmincke 1986, Houghton et al. 1996, Saucedo et al. 2017).

\section{Mixed volcanic structures}

These volcanic structures represent only $8 \%$ of volcanoes located on six positions (Fig. 2). They concentrate on either side of the road that crosses the Azrou-Timahdite plateau. In addition to the well-individualized and spatially isolated volcanic devices mentioned above which derived from dry Strombolian or wet phreatomagmatic eruptive activities, there are some few cases that witness a shifting between dry and wet dynamic style during the same monogenetic volcanic activities through different eruptive products and morphologies grouping in the same volcanic system. (Fig. 2) (Tab. 3). It is possible to spot some groupings of several volcanic products and structures over single or multiple volcanoes to form mixed eruptive morphostructures. At least three types of volcanic mixes were identified:

\section{Cone-Maar Complex}

West Hebri volcano

The volcano appears to be sealed by a maar constituting a good example of this only occurrence. It is a Strombolian cone cut by a maar at its south-western side in the same eruption. The NE-SW oriented excavation in the opened 
pozzolan quarry allows a clear gradual transition from dark and fine deposits in outer slope to reddish coarse and massive deposits near the crater's rim to be observed. (Fig. 8a). The initial Strombolian activity may be disturbed by the arrival of small amounts of water in contact of the magma. The old pozzolan quarry witness of coneshaped Strombolian deposit is cut south-westward by a beautiful cratere collapsing delimited by a tuff-ring. The presence of cauliflower bombs in pyroclastic deposit projections demonstrates the phreatomagmatic character at the end of this eruption.

\section{Maar-Cone Complex}

Lechmine Izgarn volcano

This is a mixed eruptive volcano that corresponds to an elongated maar standing along an NW-SE axis $(2500 \times 400 \mathrm{~m})$, capped by a scoria-cone on its north-western rim. It characterizes the widest
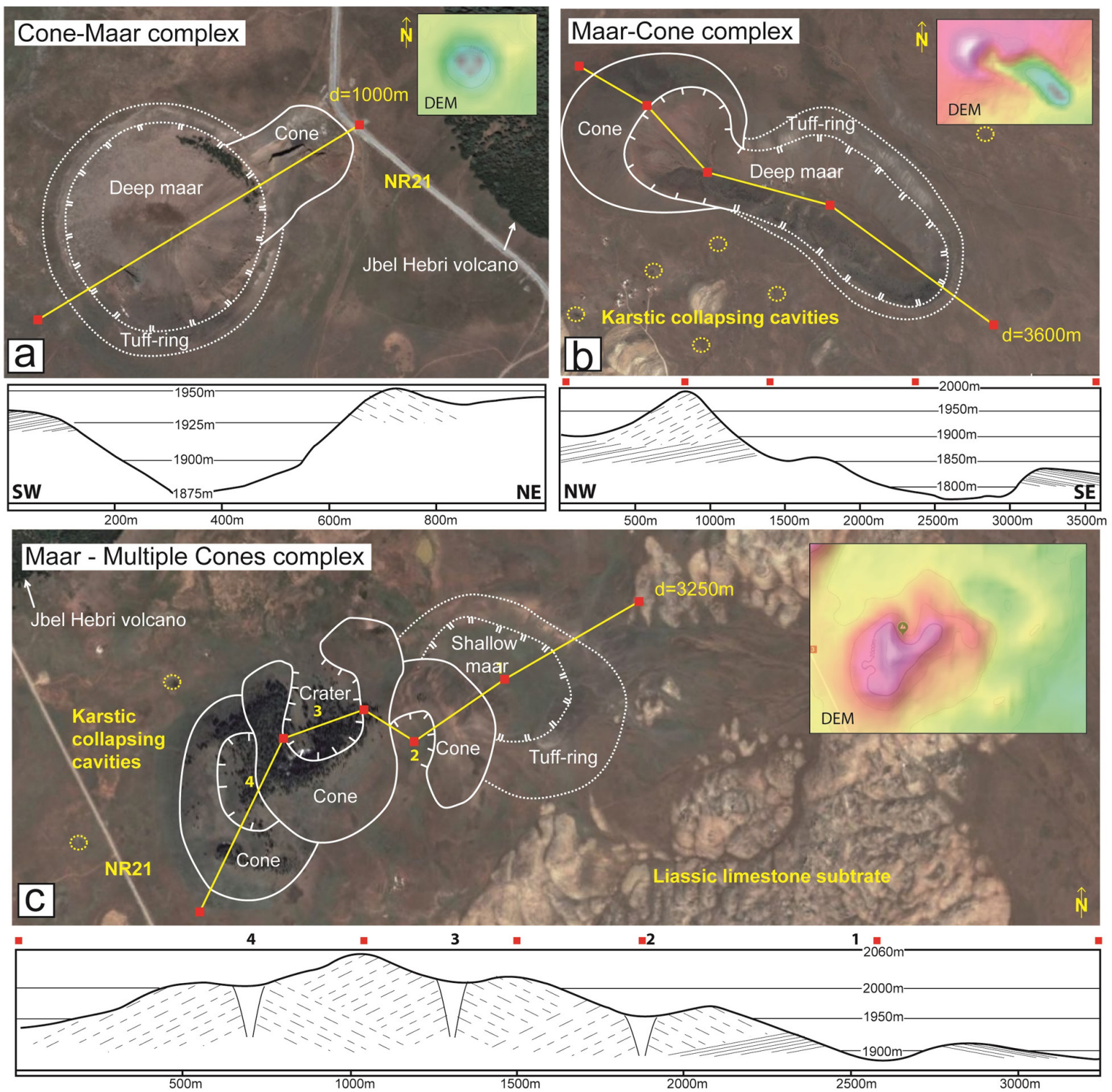

Fig. 8. Morphology, shape, and crater outline of cone-maar mixes sketched on Google satellite images jointed to the digital elevation model overview the cross-section sketch. DEM - Digital Elevation Model; NR21 - national roadway no. 21.

a) The cone-maar mixe west of Jbel Hebri; the initial cone cut in its south-western part by a late maar collapsing.

b) The elongated Izgarn mixed volcano; the initial maar is covered in the north-western part by a scoria cone, which emitted a large lava flow.

c) The Tahabrit volcanic complex; two cones followed the initial maar setting during the first eruptive phase; the second stage consists of the growth of the highest cone with a northward opened crater during a huge lava flow emission. 
maar in the MAVP. The eruptive history can sum up the main phases as follows. During the first phreatomagmatic phase, an elongated maar was formed along a tectonic fault, throwing pyroclastic breccia outside to shape a finely-bedded bordering tuff-ring. The second Strombolian phase consists of the growth of a scoria cone over the north-western crater's rim with a huge lava flow emission over the surrounding slopes. Furthermore, there are some karstic collapsing which strung along an $\mathrm{N} 70^{\circ}$ oriented fault, cross-cutting perpendicularly the elongated structure of the maar (Fig. 8b).

\section{Maar-nested Cones Complex}

Tahabrit volcano

This volcanic complex is grouping a maar and three cones along a N70 ${ }^{\circ}$ oriented fault. This complex was built during two eruptive episodes separated in time by one million years (Harmand, Cantagrel 1984). The first phase dated at 1.8 million years characterizes the initial maar formation followed by two strombolian cones on its left side. The cone beside this maar caps the western flank of its tuff-ring. The second phase occurred at 0.8 million years consisting of the eruption of a third strombolian cone over these two pre-existing ones, emitting a huge lava sheet flowing toward Lechmine-n-Kettane, Lechmine Nait Lhaj and Boulbalrhatene maars area. Because of the huge amount of very hot lava, it was able to form several tumuli and hornitos that focus around Lechmine-n-Kettane southern circumstance. There is some few karstic collapsing surrounding Tahabrit volcano (Fig. 8c).

\section{Discussion}

\section{An improved volcanic geomorphological classification}

Taking into account the range of factors intervening in the final shape of the volcanic edifices (Riedel et al. 2003, Bemis et al. 2011, Kereszturi, Németh 2012, Rodriguez-Gonzalez et al. 2012), it has been decided to use our simple and representative classification of the MAVP that includes 4 groups (lavas, cones, maars, and mixed volcanic structures) comprising 16 subgroups (Fig. 9). It is obvious that the classification suggested here is a vulgarization of the morphological features observed in this volcanic province with respect to the classification previously established by Martin (1981), which does not integrate all the volcanic structures. The morphological classification suggested has been carried out assembling both exclusive factors around the Middle-Atlas and general factors on the volcanic dynamic process in other volcanic regions around the world. It is also evident that this simple classification could be useful to apply to other Moroccan volcanic regions. Despite being simple, our summarizing classification permits grouping all lava flows and monogenetic volcanoes located in the MAVP which is affected partially by some karstic influences. Such classification has been applied to several lava flow features and about one hundred monogenetic volcanoes in the MAVP, an intracontinental basaltic field that revealed the following results.

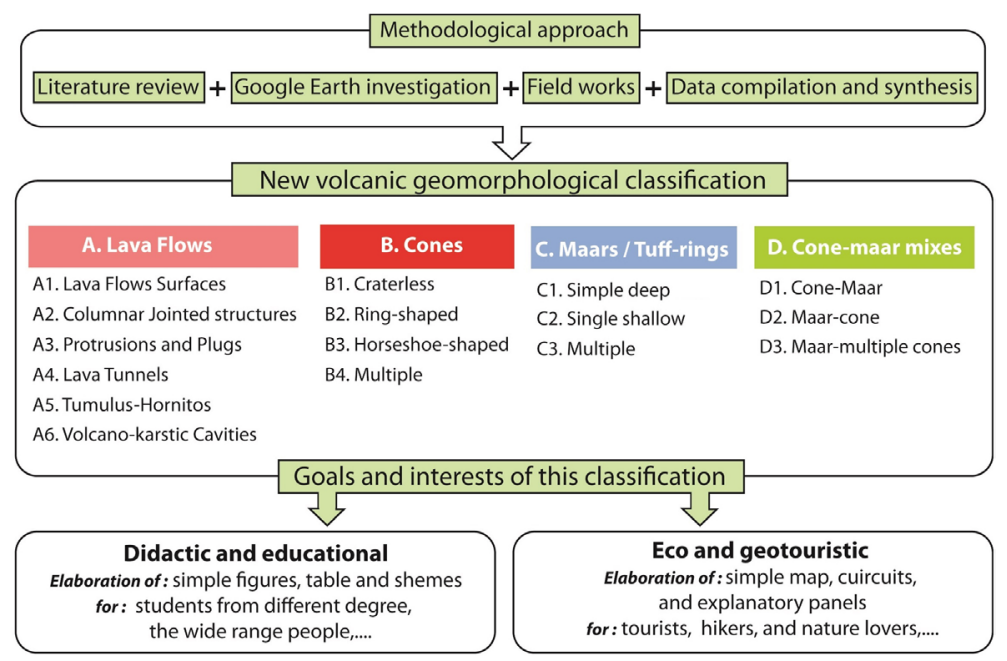

Fig. 9. Flow chart of used methodology. 


\section{Lava flow unit morphologies}

The volcanic entablature occupies about $7 \%$ of the Middle-Atlas area. Most of volcanoes concentrate on the Azrou-Timahdite plateau being or not associated with a late lava flow emission, but a fissural uprising of lavas cannot be discarded in such compressive tectonic regime. By way of its high temperature, while erupting around $1200^{\circ} \mathrm{C}$, fluid lavas were able to flow across more than $100 \mathrm{~km}$ over almost $960 \mathrm{~km}^{2}$ and fossilize some great flowing features which show how these lavas moved and reacted to environmental influences. Lava flow features witness both sudden freezing when meeting water giving rise to columnar jointed lava units and blister-caves, and/or gradual chilling within lava bodies, especially when the external surface cools rapidly but the melted core stays progressing forward. The karstification has contributed to the configuration of Azrou-Timahdite volcanism and has interacted mechanically and chemically to produce some great crypto-karstic collapsing cavities below 100 $\mathrm{m}$ diameter.

\section{Volcanoes types and Morphologies}

The Azrou-Timahdite plateau holds most of volcanoes that seem to emerge from a large lava flow to form an $\mathrm{N} 170^{\circ}$ oriented major trend crossed by few secondary $\mathrm{N} 60-70^{\circ}$ oriented alignments. Cones characterize the dominant volcanic monogenetic landforms (66\%), followed by maars/tuff-rings (26\%) and finally few mixes between these two landforms $(8 \%)$. There are
$50 \%$ of cones without crater that includes the oldest and relatively eroded structures, 32\% horseshoe-shaped cones seem to be associated usually to synchronic lava emission, $14 \%$ ring-shaped cones represent low external influences to reach a perfect shape, and finally, multiple cones of Boutagrouine with 8 nested cones which emerged from two parallel fractures (Fig. 10a). There are $40 \%$ of deep maars, $40 \%$ of shallow maars, and $20 \%$ of maar complexes (Fig. 10b).

The quantitative classification that we have applied is based on the elongation index, which allows us to delimit between the morphologies of the craters and permit to draw summarizing graphs that provide an idea about the participation percentage of each category. We were enthused from (Dóniz-Páez 2015) that used these morphometric parameters of elongation to limit between these categories as follows: (1.0) circular, (1.0-1.2) sub-circular, (1.3-1.5) sub-elliptic, (1.61.9) elliptic, (2-2.2) elliptic elongated. We noticed that most of the volcanoes tends to possess a circular type, but the higher the index is raised the more the prevalence is reduced.

The Azrou-Timahdite plateau includes the largest number of maars in Morocco because of the widespread of the underlying Liassic aquifer that causes their formation under explosive magma-water interaction. There are $72 \%$ of simple maar and $28 \%$ of complex ones. Deep and wide maars craters are linked to an optimal magma-water ratio interacting in deep. Shallow and small maar craters are mostly related to shallow

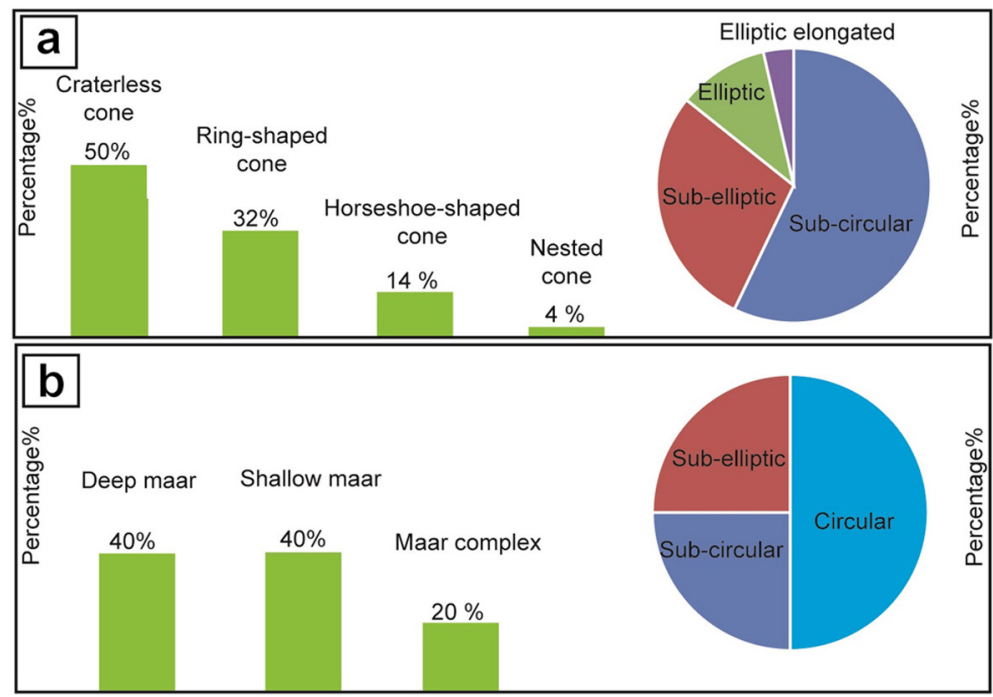

Fig. 10. Morphological classification of cones (a) and maars (b). 
or superficial magma-water interaction. Mixed eruptive volcanoes, which represent $8 \%$, are induced from a fluctuating water-magma ratio during the eruption, which could be the result of sudden precipitation leading to superficial water flowing, and/ or rise of the water table level. The morphological classification proposed has been carried out attending not only to exclusive factors appearing in the MAVP (Martin 1974, 1981, Menjour et al. 2017), but to general factors controlling volcanic processes that are also present in other volcanic regions (Kilburn 2000, Walker, Sigurdsson 2000, Kereszturi, Németh 2012, Dóniz-Páez 2015, Harris, Rowland 2015).

\section{Intervening factors in morphostructural geodiversity}

\section{Structural factor}

During the Neogene to Plio-quaternary period, the Middle-Atlas region was under a compressive slip-strike tectonic regime. This may be favoured the opening of stress slots during the reactivation of late-Hercynian accidents as response to the maximum sub-meridian stress (Fedan, Thomas 1986), which could explain the orientation of the main volcanic trail that crosses perpendicularly major faults. Even, continuous tectonic movement along these faults could participate mechanically to develop karstification (Martin 1974, 1981, Menjour et al. 2017).

\section{Magmatic factor}

The under-saturated nature and the high setting temperatures $\left(1100-1200^{\circ} \mathrm{C}\right.$ ) (Taddeucci et al. 2015) gave lavas ability to spread easily covering almost the entire Azrou- Timahdite plateau which accounts for nearly $7 \%$ of the Middle-Atlas area. Lavas flowed over great distances before cooling and solidifying because of its rheological properties. This magma rises rapidly due to its hyper alkaline nature as proven by the mantle and lower crust xenoliths occurrence (Harmand, Moukadiri 1986, Hernandez et al. 1987, El Azzouzi 2002, Lenaz et al. 2014, Chanouan et al. 2016, Mavrogonatos et al. 2016).

\section{Lithological and climatic factors}

Most of the MAVP area is characterized by a highly fractured and strongly karstified limestone substrate forming a great aquifer. In addition, high snowy and rainy precipitation estimated to be about $730 \mathrm{~mm}$ per year as (Bentayeb, Leclerc 1977), and the advanced basement karstification state make of the Middle-Atlas an efficient water receptacle that represents the main water reservoir of Morocco (Lepoutre et al. 1966, Bentayeb, Leclerc 1977, Peyron 1980, Malaki 2006, Menjour et al. 2017), from which extend the major hydrographic systems toward the Atlantic and the Mediterranean coastline.

\section{Educational and Geotouristic vocation}

The MAVP region found a major motivational theme for tourism and educational activities throughout this part of the Middle-Atlas. The reliefs erected by the volcanoes contribute to an exceptional richness of landscapes, which does part of the Ifrane Natural Park.

\section{Educational potential}

Based on our proposed table, figures, and schemes, the MAVP provides an amazing geological area to see some volcanological phenomena on well-preserved and easily accessible volcanic outcrops and remains an excellent area for field trips to find clear and simple observations about the volcanic process. Considering its central geographical location and the high scientific importance, this volcanic region remains a favourable field gathering teachers and students from all over Morocco. These various volcanic sites are promotional tools to develop an educational tourism category for curious about universal geological phenomena, such as volcanic eruptions.

\section{Geotouristic potential}

Using this proposed volcanic geomorphological map, incoming tourists will find various and attractive hiking trails crossing valleys and cedar forests amid of vast volcanic scenes. For those, Azrou and Timahdite cities will meet all accommodation requirements. Especially, volcanic structures line the road between Azrou and Timahdite towns, just a few tens of metres on either side make it easier to get. Jbel Hebri and Michlifene accommodation centres occur right amid of the main volcanic landscapes.

Indeed, this MAVP is considered as a little Auvergne by (Martin 1981) and present some assets (De Waele et al. 2005, Malaki 2006, El Wartiti 
et al. 2009). This volcanic field needs to be promoted as other well-known foreign volcanic provinces, such as the Volcanoes of Auvergne in France, the Hawaii Volcanoes National Park in the USA, Garrotxa Volcanic Zone Natural Park in Spain, Wudalianchi National Park in China, and Al Madinah Volcanic Field in Saudi Arabia. A good promotion with the collaboration of the Natural Park of Ifrane could allow initiating an interesting geotourism activity around these volcanic sites to support sustainable socio-economic opportunities for the whole region.

The volcanic buildings situated in the tabular plateau of the Middle-Atlas in Morocco show special eruptive structures. This natural element could be used for its impressive landscapes, to create a touristic lever, and a territory development support. An action plan remains to be proposed for the development and the patrimonial appropriation of this geosite within a project which reunites the natural and human assets of the region.

\section{Conclusion}

A morphological classification of the MAVP monogenetic volcanic field is proposed based on the earlier literature data capitalization combined with wide fieldwork results focusing on all volcanic landscapes. We suggested here a volcano-morphological arrangement, which takes into account of both prevailing eruptive dynamics and hydrogeological karstic influences.

In contrast to the other Moroccan PlioQuaternary volcanic provinces that seem to be dominated by Strombolian cones emitting some lava flow units, the MAVP domain offers several volcanic morphostructural features because of the participation of three eruptive dynamic style: Hawaiian (lava flows units), Strombolian (cones) and phreatomagmatic (maar/tuff-ring). The duality between inner and external factors, particularly when some encompassing water masses showed up or vanished all through the eruption lifespan, gives rise to some unusual mixed volcanic devices characterizing the MAVP originality.

The classification proposed here consists of four large geomorphological groups of 16 subgroups:

1. lava flows units (6 subgroups),

2. cones (4 subgroups),
3. maars associated or not to tuff-rings (3 subgroups),

4. cone-maar mixes (3 subgroups). Morphologic parameters acoounted for the classification are the main eruptive dynamic style, shapes, position, shape of the crater, and the associated pyroclastic products.

The hydrogeological karstic framework has triggered this diversity due to the widespread of an underlying Liassic limestone aquifer that may interact explosively with magmas to produce great hydrovolcanic landforms. All these volcanological classes seem to concentrate on the Azrou-Timahdite plateau from either side of the national road making it easy to access.

The MAVP provides an easy access geological area to appreciate some unusual volcanological phenomena on well-preserved volcanic outcrops, gathering teachers and students from all over Morocco.

This young basaltic province presents some assets and needs to be promoted as the other well-known foreign volcanic provinces. A good promotion with the teamwork of the Natural Park of Ifrane could allow initiating an interesting geotourism activity around these volcanic sites to support sustainable socio-economic development for the whole region.

We believe that our contribution will enlarge the scientific knowledge about the evolution of volcanic phenomena from MAVP, and exhaust its scientific and geotouristic potential and assets, especially in this high-mountain part of the Moroccan-Atlas chain which holds mostly a poor native population.

\section{Acknowledgments}

This work takes part of the V2GV project framework (Valuating of Volcanic Geo-Materials and Geo-Sites in Morocco), supported and financed by Hassan II Academy of Science and Techniques (AH2ST), and staged in partnership with the Faculty of Sciences of Hassan II University - Casablanca, the Scientific Institute in Rabat and the Faculty of Science and Techniques of Hassan II University - Mohammadia, and the Laboratoire des Magmas et Volcans in France that we would like to thank very warmly. We also thank readers for their remarks and the reviewers for their constructive suggestions. 


\section{Author's contribution}

Abdelmounji Amine - 15\%, Iz-Eddine El Amrani El Hassani - 15\%, Toufik Remmal - 15\%, Fouad El Kamel - 15\%, Benjamin Van Wyk de Vries - 20\%, Pierre Boivin - 20\%.

\section{References}

Amraoui F., Razack M., Bouchaou L., 2004. Comportement d'une source karstique soumise à une sécheresse prolongée: la source Bittit (Maroc). Comptes Rendus Geoscience, 336(12): 1099-1109.

Anderson S.W., Smrekar S.E., Stofan E.R., 2012. Tumulus development on lava flows: insights from observations of active tumuli and analysis of formation models. Bulletin of Volcanology 74(4): 931-946. DOI: 10.1007/s00445-0120576-2.

Applegarth L.J., Pinkerton H., James M.R., Calvari S., 2010. Lava flow superposition: The reactivation of flow units in compound'a'ā flows. Journal of Volcanology and Geothermal Research 194(4): 100-106.

Bardintzeff J.-M., 2011. Les éruptions laviques. In: Volcanologie - 4ème édition, Dunod, Paris: 83-84.

Batiza R., White J.D.L., 2000. Submarine Lavas and Hyalo-clastite. In: Encyclopedia of volcanoes: 361-381.

Bemis K., Walker J., Borgia A., Turrin B., Neri M., Swisher III C., 2011. The growth and erosion of cinder cones in Guatemala and El Salvador: models and statistics. Journal of Volcanology and Geothermal Research 201(1-4): 39-52.

Bentayeb A., Leclerc C., 1977. Le Causse moyen atlasique. In: Ressources En Eaux Du Maroc, Domaines Atlasiques et Sud-Atlasiques, Editions du service géologique du Maroc, Rabat: Tome III: 37-66.

Boivin P., 2017. Les prismes basaltiques. Bulletin Historique et Scientifique de l'Auvergne, tome CXV/2, nos 802-803, juillet-décembre 2014, 24 p.

Boivin P., Besson J.-C., Briot D., Camus G., de Goër de Hevre A., Gourgaud A., Labazuy P., de Larouzière F.-D., Livet M., Mergoil J., Miallier D., Morel J.-M., Vernet G., Vincent P., 2004. Volcanologie de la Chaîne des Puys, carte fascicule 5è édition, bilingue français - anglais. Editions Du Parc Régional Des Volcans d'Auvergne.

Boivin P., Besson J.-C., Briot D., Camus G., de Goër de Hevre A., Gourgaud A., Labazuy P., de Larouzière F.D., Livet M., Mergoil J., Miallier D., Morel J.-M., Vernet G., Vincent P., 2009. Volcanologie de la Chaîne des Puys, 4è édition bilingue. Editions Du Parc Régional Des Volcans d'Auvergne, Aydat, 179.

Boivin P., Bourdier J.L., Camus G., de Goer de Herve A., Gourgaud A., Kieffer G., Mergoil J., Vincent P.M., Auby R., 1982. Influence de la Nature des Magmas sur l'Activité Phréatomagmatique: Approche Volcanologique et Thermodynamique. Bulletin Volcanologique 45(1): 25-39.

Boivin P., Gourgaud A., 1978. Synchronisme des dynamismes de type «maar» et «strombolien» près de La Sauvetat (Sud-Devès-Massif central français). Comptes rendus sommaires des séances de la Société géologique de France Paris 1: 24-27.

Brand B.D., Clarke A.B., 2009. The architecture, eruptive history, and evolution of the Table Rock Complex, Oregon: From a Surtseyan to an energetic maar eruption. Journal of Volcanology and Geothermal Research 180(2-4): 203-224.
Büchel G., 1993. Maars of the Westeifel, Germany. In: Paleolimnology of European maar lakes. Springer, Berlin, Heidelberg: 1-13.

Büchel G., Negendank J.F.W., Wuttke M., Viereck L., 2000. Quaternary and Tertiary Eifel maars, Enspel (Westerwald) and Laacher See: Volcanology, sedimentology and hydrogeology. In: Field trip guidebook. International Maar Conference, Daun/Vulkaneifel (Germany): 17-27.

Camus G., Vincent J.-M., 1973. Le Chuquet Genestoux et les projections palagonitiques du maar d'Enval. Revue des Société d'histoire naturelle d'Auvergne 39(1-4): 1-12.

Carracedo Sánchez M., Sarrionandia F., Arostegui J., Eguiluz L., Gil Ibarguchi J.I., 2012. The transition of spatter to lava-like body in lava fountain deposits: features and examples from the Cabezo Segura volcano (Calatrava, Spain). Journal of Volcanology and Geothermal Research 227-228: 1-14.

Chanouan L., Ikenne M., Gahlan H.A., Arai S., Youbi N., 2016. Petrological characteristics of mantle xenoliths from the Azrou-Timahdite quaternary basalts, middle atlas, Morocco: A mineral chemistry perspective. Journal of African Earth Sciences 127: 235-252.

Charriere A., 1984. Évolution néogène de bassins continentaux et marins dans le Moyen Atlas central (Maroc). Bulletin de La Société Géologique de France 7(6): 1127-1136.

Chough S.K., Sohn Y.K., 1990. Depositional mechanics and sequences of base surges, Songaksan tuff ring, Cheju Island, Korea. Sedimentology 37(6): 1115-1135. DOI: 10.1111/j.1365-3091.1990.tb01849.x.

Clarke H., Troll V.R., Carracedo J.C., 2009. Phreatomagmatic to Strombolian eruptive activity of basaltic cinder cones: Montaña Los Erales, Tenerife, Canary Islands. Journal of Volcanology and Geothermal Research 180(2-4): 225-245. DOI: 10.1016/j.jvolgeores.2008.11.014.

Clarke H., Troll V.R., Carracedo J.C., Byrne K., Gould R., 2005. Changing eruptive styles and textural features from phreatomagmatic to strombolian activity of basaltic littoral cones: Los Erales cinder cone, Tenerife, Canary Islands. Estudios Geológicos 61(3-6): 121-134. DOI: 10.3989/ egeol.05613-650.

de Silva S., Lindsay J.M., 2015. Primary Volcanic Landforms. In: H. Sigurdsson (Ed.), The Encyclopedia of Volcanoes (Second Edition), Academic Press, Amsterdam: 273-297. DOI: 10.1016/B978-0-12-385938-9.00015-8.

De Waele J., Di Gregorio F., El Wartiti M., Malaki A., Melis M.T., 2005. Carta dei geomorfositi e della geodiversità d'Ifrane-Azrou (Medio Atlante, Marocco). In: $A A$. $V V$. (ed.), 9 Conferenza ASITA, Catania: 939-944.

De Waele J., Di Gregorio F., Melis M.T., El Wartiti M., 2008. Landscape units, geomorphosites and geodiversity of the Ifrane Azrou region (Middle Atlas, Morocco). Memorie Descriptive. Carta Geolologica d'Italia LXXXVII: 63-76.

Diniega S., Németh K., 2014. Tumulus. In: Encyclopedia of Planetary Landforms, Springer, New York: 1-6. DOI: 10.1007/978-1-4614-9213-9_387-1.

Dóniz-Páez J., 2015. Volcanic geomorphological classification of the cinder cones of Tenerife (Canary Islands, Spain). Geomorphology 228: 432-447.

Dóniz-Páez J., Becerra-Ramírez R., Guillén-Martín C., González-Cárdenas E., Escobar-Lahoz E., 2008. Patrimonio geomorfológico del complejo volcánico de la Corona de El Lajial (El Hierro, Islas Canarias, España). X.Ubeda, D.Vericat, R.J.Batalla (ed.), Avances de La Geomorfología En España, 2010: 361-364. 
Dragoni M., Piombo A., Tallarico A., 1995. A model for the formation of lava tubes by roofing over a channel. Journal of Geophysical Research: Solid Earth 100(B5): 8435-8447. DOI: $10.1029 / 94 J B 03263$.

Dragoni M., Santini S., 2007. Lava flow in tubes with elliptical cross sections. Journal of Volcanology and Geothermal Research 160(3): 239-248.

El Arabi H., Ouahhabi B., Charriere A., 2001. Les series du Toarcien-Aalenien du SW du Moyen-Atlas (Maroc); precisions stratigraphiques et signification paleogeographique. Bulletin de La Société Géologique de France 172(6): 723-736.

El Azzouzi M., 2002. Volcanisme Calco-Alcalin et Alcalin en Contexte Post-Collision Continentale: Exemple du Maroc. These d'état. Univ. Mohammed V, Rabat.

El Azzouzi M., Maury R.C., Bellon H., Youbi N., Cotten J., Kharbouch F., 2010. Petrology and K-Ar chronology of the Neogene-Quaternary Middle Atlas basaltic province, Morocco. Bulletin de La Société Géologique de France 181(3): 243-257.

El Wartiti M., Malaki A., Zahraoui M., Di Gregorio F., De Waele J., 2009. Geosites and touristic development of the Northwestern Tabular Middle Atlas of Morocco. In: Desertification and risk analysis using high and medium resolution satellite data, Springer: 143-156.

Fedan B., 1989. Evolution géodynamique d'un bassin intraplaque sur décrochements: le Moyen Atlas (Maroc) durant le Méso-Cénozoïque. Travaux de l'Institut scientifique. Série géologie et géographie physique, $\mathrm{n}^{\circ} 18$.

Fedan B., Thomas G., 1986. Découverte de dépôts néogenes déformés par I'accident nord-moyen-atlasique (Maroc). Implications Sur Son Activité Mio-Plio-Quaternaire Au Norde de Boulemane. Géolgie Méditerranéeane, Tome XII-XIII (1985-1986), n³-4, 13(4) : 151-154.

Fisher R.V., 1977. Erosion by volcanic base-surge density currents: U-shaped channels. Geological Society of America Bulletin 88(9): 1287-1297.

Fisher R.V., 1979. Models for pyroclastic surges and pyroclastic flows. Journal of Volcanology and Geothermal Research 6(3): 305-318.

Fisher R.V., Waters A.C., 1970. Base surge bed forms in maar volcanoes. American Journal of Science 268(2): 157-180.

Giordano D., Polacci M., Papale P., Caricchi L., 2010. Rheological control on the dynamics of explosive activity in the 2000 summit eruption of Mt. Etna. Solid Earth 1: 61-69.

Goehring L., Morris S.W., 2008. Scaling of columnar joints in basalt. Journal of Geophysical Research: Solid Earth 113(B10): B10203. DOI: 10.1029/2007JB005018.

Harmand C., Cantagrel J.M., 1984. Le volcanisme alcalin Tertiaire et Quaternaire du Moyen Atlas (Maroc): chronologie K/Ar et cadre géodynamique. Journal of African Earth Sciences (1983) 2(1): 51-55.

Harmand C., Moukadiri A., 1986. Synchronisme entre tectonique compressive et volcanisme alcalin; exemple de la province quaternaire du Moyen Atlas (Maroc). Bulletin de La Societe Geologique de France 2(4): 595-603.

Harris A.J., Rowland S.K., 2015. Lava flows and rheology. In: The Encyclopedia of Volcanoes (Second Edition), Elsevier: 321-342.

Head III J.W., Wilson L., 1989. Basaltic pyroclastic eruptions: influence of gas-release patterns and volume fluxes on fountain structure, and the formation of cinder cones, spatter cones, rootless flows, lava ponds and lava flows. Journal of Volcanology and Geothermal Research 37(3): 261271.
Hernandez J., de Larouziere F.D., Bolze J., Bordet P., 1987. Le magmatisme néogène bético-rifain et le couloir de décrochement trans-Alboran. Bulletin de La Société Géologique de France 3(2): 257-267.

Hon K., Gansecki C., Kauahikaua J., 2003. The Transition from 'A'a to Pāhoehoe Crust on Flows. US Geological Survey Professional Paper 1676: 1-89.

Hooten J.A., Ort M.H., 2002. Peperite as a record of early-stage phreatomagmatic fragmentation processes: an example from the Hopi Buttes volcanic field, Navajo Nation, Arizona, USA. Journal of Volcanology and Geothermal Research 114(1): 95-106.

Houghton B.F., Gonnermann H.M., 2008. Basaltic explosive volcanism: constraints from deposits and models. Chemie Der Erde-Geochemistry 68(2): 117-140.

Houghton B.F., Schmincke H.-U., 1986. Mixed deposits of simultaneous strombolian and phreatomagmatic volcanism: Rothenberg volcano, east Eifel volcanic field. Journal of Volcanology and Geothermal Research 30(1): 117-130. DOI: 10.1016/0377-0273(86)90069-7.

Houghton B.F., Wilson C.J.N., Rosenberg M.D., Smith I.E.M., Parker R.J., 1996. Mixed deposits of complex magmatic and phreatomagmatic volcanism: an example from Crater Hill, Auckland, New Zealand. Bulletin of Volcanology 58(1): 59-66. DOI: 10.1007/s004450050126.

Kereszturi G., Németh K., 2012. Monogenetic basaltic volcanoes: genetic classification, growth, geomorphology and degradation. In: K.Németh (ed.), Updates in Volcanology New Advances in Understanding Volcanic Systems, InTech: 3-88.

Kereszturi G., Németh K., Csillag G., Balogh K., Kovács J., 2011. The role of external environmental factors in changing eruption styles of monogenetic volcanoes in a Mio/Pleistocene continental volcanic field in western Hungary. Journal of Volcanology and Geothermal Research 201(1-4): 227-240. DOI: 10.1016/j.jvolgeores.2010.08.018.

Kilburn C.R., 2000. Lava flows and flow fields. H.Sigurdsson, B.Houghton, S.McNutt, H.Rymer, J.Stix (eds.) Encyclopedia of volcanoes. Academic Press, San Diego: 291-305.

Kilburn, C. R., 2004. Fracturing as a quantitative indicator of lava flow dynamics. Journal of Volcanology and Geothermal Research, 132(2-3), 209-224.

Kshirsagar P., Siebe C., Guilbaud M.N., Salinas S., 2016. Geological and environmental controls on the change of eruptive style (phreatomagmatic to Strombolian-effusive) of Late Pleistocene El Caracol tuff cone and its comparison with adjacent volcanoes around the Zacapu basin (Michoacán, México). Journal of Volcanology and Geothermal Research 318: 114-133.

Lagmay A.M.F., Vries B. van W. de, Kerle N., Pyle D.M., 2000. Volcano instability induced by strike-slip faulting. Bulletin of Volcanology 62(4-5): 331-346. DOI: 10.1007/ s004450000103.

Lenaz D., Youbi N., De Min A., Boumehdi M.A., Ben Abbou M., 2014. Low intra-crystalline closure temperatures of Cr-bearing spinels from the mantle xenoliths of the Middle Atlas Neogene-Quaternary Volcanic Field (Morocco): Mineralogical evidence of a cooler mantle beneath the West African Craton. American Mineralogist 99(2-3): 267-275. DOI: 10.2138/am.2014.4655

Lepoutre B., Martin J., Chamayou J., 1966. Le Causse moyen-Atlasique. Le Causse moyen-atlasique. Les cahiers de la recherche agronomique $n^{\circ} 24$ 1967. Congrès de Pédologie Méditerranéenne, Madrid (ES), 1966/09. Excursion au 
Maroc livret-guide: tome 2. Descriptions des régions traversées, Chapitre 4, 207-226 p.

Lorenz V., 1973. On the formation of maars. Bulletin Volcanologique 37(2): 183-204.

Lorenz V., 1984. Explosive volcanism of the West Eifel volcanic field/Germany. In: Developments in Petrology 11: 299-307.

Lorenz V., 1986. On the growth of maars and diatremes and its relevance to the formation of tuff rings. Bulletin of Volcanology 48(5): 265-274. DOI: 10.1007/BF01081755.

Lorenz V., Suhr P., Goth K., 2003. Maar-Diatrem-Vulkanismus-Ursachen und Folgen. Die Guttauer Vulkangruppe in Ostsachsen als Beispiel fur die komplexen Zusammenhange. Zeitschrift Fur Geologische Wissenschaften 4(6): 267-312.

Lorenz V., Suhr P., Suhr S., 2016. Phreatomagmatic maar-diatreme volcanoes and their incremental growth: a model. Geological Society, London, Special Publications 446 29-59. DOI: $10.1144 / S P 446.4$.

Malaki A., 2006. Géosites: Intérêt scientifique, patrimoine culturel et visées socio-économiques, au niveau d'Ifrane, Azrou, Aîn leuh et El Hajeb (causse moyen at-lasique). Thèse de doctorat national en géologie, Faculté des Sciences de Rabat: 105-247.

Martin J., 1974. Les trous du plateau d'Azrou: un exemple de cryptokarst. Mémoires et Documents, Nouvelle séries, vol. 15. Phénomènes karstiques, tome II 161-175.

Martin J., 1981. Le Moyen Atlas central étude géomorphologique. Ed. du Service géologique du Maroc. Notes et Mémoires Service Géologique du Maroc 258 bis: 248-340.

Mavrogonatos K., Flemetakis S., Papoutsa A., Klemme S., Berndt J., Economou G., Pantazidis A., Baziotis I., Asimow P.D., 2016. Phosphorus Zoning From Secondary Olivine In Mantle Xenolith From Middle Atlas Mountains (Morocco, Africa): Implications For Crystal Growth Kinetics. Bulletin of the Geological Society of Greece 50(4): 1923-1932.

Menjour F., Remmal T., Hakdaoui M., Kamel F. E., Lakroud K., Amraoui F., El Amrani El Hassani I., Van Wyk de Vries B., Boivin P., 2017. Role of Fracturing in the Organization of the Karst Features of Azrou Plateau (Middle Atlas, Morroco) Studied by Remote Sensing Imagery. Journal of the Indian Society of Remote Sensing 4596: 1015-1030. DOI: $10.1007 / \mathrm{s} 12524-016-0646-6$.

Miche H., Saracco G., Mayer A., Qarqori K., Rouai M., Dekayir A., Chalikakis K., Emblanch C., 2018. Hydrochemical constraints between the karst Tabular Middle Atlas Causses and the Saiis basin (Morocco): implications of groundwater circulation. Hydrogeology Journal 26(1): 7187. DOI: $10.1007 /$ s10040-017-1675-0.

Mountaj S., Remmal T., El Hassani El Amrani I., Van Wyk De Vries B., Boivin P., 2014. Reconstruction of the morphological evolution and the eruptive dynamics of the Lachemine n'Ait el Haj Maar in the Middle Atlas. Karstic province of Morroco. In: Proceedings 5th International Maar Conference, Queretaro, Mexico: 4-5.

Neri A., Papale P., Macedonio G., 1998. The role of magma composition and water content in explosive eruptions: 2. Pyroclastic dispersion dynamics. Journal of Volcanology and Geothermal Research 87(1-4): 95-115. DOI: 10.1016/ S0377-0273(98)00102-4

Németh K., 2012. An Overview Of The Monogenetic Volcanic Fields Of The Western Pannonian Basin: Their Field Characteristics And Outlook For Future Research From A Global Perspective. In: F.Stoppa (ed.), Updates In Vol- canology - A Comprehensive Approach To Volcanological Problems. Intech, Rijeka, Croatia, 27-52 p.

Németh K., Haller M. J., Martin U., Risso C., Massaferro G., 2008. Morphology of lava tumuli from Mendoza (Argentina), Patagonia (Argentina), and Al-Haruj (Libya). Zeitschrift Fuer Geomorphologie 52(2): 181-194.

Németh K., Martin U., Harangi S., 2001. Miocene phreatomagmatic volcanism at Tihany (Pannonian Basin, Hungary). Journal of Volcanology and Geothermal Research 111(1): 111-135.

Németh K., White J.D.L., 2003. Reconstructing eruption processes of a Miocene monogenetic volcanic field from vent remnants: Waipiata Volcanic Field, South Island, New Zealand. Journal of Volcanology and Geothermal Research 124(1-2): 1-21. DOI: 10.1016/S0377-0273(03)00042-8.

Németh K., White J.D.L., 2009. Miocene phreatomagmatic monogenetic volcanism of the Waipiata Volcanic Field, Otago, New Zealand. In: I.M.Turnbull (ed.), Field Trip Guides, Geosciences 09 Conference, Oamaru, New Zealand. Geological Society of New Zealand Miscellaneous Publication 128B: 134.

Ort M.H., Elson M.D., Anderson K.C., Duffield W.A., Samples T.L., 2008. Variable effects of cinder-cone eruptions on prehistoric agrarian human populations in the American southwest. Journal of Volcanology and Geothermal Research 176(3): 363-376. DOI: 10.1016/j.jvolgeores.2008.01.031

Paguican E.M.R., Bursik M.I., 2016. Tectonic Geomorphology and Volcano-Tectonic Interaction in the Eastern Boundary of the Southern Cascades (Hat Creek Graben Region), California, USA. Frontiers in Earth Science 4. DOI: 10.3389 /feart.2016.00076.

Parfitt E.A., 2004. A discussion of the mechanisms of explosive basaltic eruptions. Journal of Volcanology and Geothermal Research 134(1-2): 77-107. DOI: 10.1016/j.jvolgeores.2004.01.002.

Parfitt E.A., Wilson L., 1995. Explosive volcanic eruptionsIX. The transition between Hawaiian-style lava fountaining and Strombolian explosive activity. Geophysical Journal International 121(1): 226-232.

Peterson D.W., Tilling R.I., 1980. Transition of basaltic lava from pahoehoe to aa, Kilauea Volcano, Hawaii: Field observations and key factors. Journal of Volcanology and Geothermal Research 7(3): 271-293. DOI: 10.1016/03770273(80)90033-5.

Peyron M., 1980. Les chutes de neige dans l'Atlas marocain. Revue de Géographie Alpine 68(3): 237-254.

Riedel C., Ernst G.G. J., Riley M., 2003. Controls on the growth and geometry of pyroclastic constructs. Journal of Volcanology and Geothermal Research 127(1-2): 121-152.

Rodriguez-Gonzalez A., Fernandez-Turiel J. L., Perez-Torrado F. J., Paris R., Gimeno D., Carracedo J. C., Aulinas M., 2012. Factors controlling the morphology of monogenetic basaltic volcanoes: The Holocene volcanism of Gran Canaria (Canary Islands, Spain). Geomorphology 136(1): 31-44.

Romero C., 1991. Las manifestaciones volcánicas históricas del Archipiélago Canario (Tomo I). University of La Laguna, Sta. Cruz de Tenerife (Spain).

Romero C., 1992. Estudio geomorfológico de los volcanes históricos de Tenerife. ACT, Santa Cruz de Tenerife, $265 \mathrm{p}$.

Rosseel J.-B., White J.D.L., Houghton B.F., 2006. Complex bombs of phreatomagmatic eruptions: Role of agglomeration and welding in vents of the 1886 Rotomahana eruption, Tarawera, New Zealand. Journal 
of Geophysical Research Solid Earth 111(B12205). DOI: 10.1029/2005JB004073.

Saucedo R., Macías J.L., Ocampo-Díaz Y.Z.E., Gómez-Villa W., Rivera-Olguín E., Castro-Govea R., Sánchez-Núñez J.M., Layer P.W., Torres Hernández J.R., Carrasco-Núñez G., 2017. Mixed magmatic-phreatomagmatic explosions during the formation of the Joya Honda maar, San Luis Potosí, Mexico. Geological Society, London, Special Publications 446(1): 255-279. DOI: 10.1144/SP446.11.

Schmincke H.-U., Fisher R.V., Waters A.C., 1973. Antidune and chute and pool structures in the base surge deposits of the Laacher See area, Germany. Sedimentology 20(4): 553-574.

Schumacher R., Schmincke H.-U., 1995. Models for the origin of accretionary lapilli. Bulletin of Volcanology 56(8): 626-639. DOI: 10.1007/BF00301467.

Sheridan M.F., Wohletz K.H., 1983. Hydrovolcanism: basic considerations and review. Journal of Volcanology and Geothermal Research 17(1): 1-29.

Siebe C., 1986. On the possible use of cinder cones and maars as palaeoclimatic indicators in the closed basin of Serdanoriental, Puebla, México. Journal of Volcanology and Geothermal Research 28(3-4): 397-400.

Skacelova Z., Rapprich V., Valenta J., Hartvich F., Sramek J., Radon M., Gaždová R., Nováková L., Kolínský P., Pécskay Z., 2010. Geophysical research on structure of partly eroded maar volcanoes: Miocene Hnojnice and Oligocene Rychnov volcanoes (northern Czech Republic). Journal of Geosciences 55(4): 333-345. DOI: 10.3190/ jgeosci.072.

Skilling I.P., White J.D.L., McPhie J., 2002. Peperite: a review of magma-sediment mingling. Journal of Volcanology and Geothermal Research 114(1): 1-17.

Spry A., 1962. The origin of columnar jointing, particularly in basalt flows. Journal of the Geological Society of Australia 8(2): 191-216. DOI:10.1080/14400956208527873.

Stárková M., Rapprich V., Breitkreuz C., 2012. Variable eruptive styles in an ancient monogenetic volcanic field: examples from the Permian Levín Volcanic Field (Krkonoše Piedmont Basin, Bohemian Massif). Journal of Geosciences 56(2): 163-180. DOI: 10.3190/jgeosci.095.

Strong M., Wolff J., 2003. Compositional variations within scoria cones. Geology 31(2): 143-146.

Sumner J.M., 1998. Formation of clastogenic lava flows during fissure eruption and scoria cone collapse: the 1986 eruption of Izu-Oshima Volcano, eastern Japan. Bulletin of Volcanology 60(3): 195-212.
Sumner J.M., Blake S., Matela R.J., Wolff J.A., 2005. Spatter. Journal of Volcanology and Geothermal Research 142(1): 4965.

Taddeucci J., Edmonds M., Houghton B., James M.R., Vergniolle S., 2015. Hawaiian and Strombolian eruptions. The Encyclopedia of Volcanoes, 2nd Edn. Academic Press, Amsterdam: 485-503.

Traglia F.D., Cimarelli C., Rita D. de, Torrente D.G., 2009. Changing eruptive styles in basaltic explosive volcanism: Examples from Croscat complex scoria cone, Garrotxa Volcanic Field (NE Iberian Peninsula). Journal of Volcanology and Geothermal Research 180(2-4): 89-109. DOI: 10.1016/j.jvolgeores.2008.10.020.

Vergniolle S., Brandeis G., 1996. Strombolian explosions: 1. A large bubble breaking at the surface of a lava column as a source of sound. Journal of Geophysical Research: Solid Earth 101(B9): 20433-20447.

Vespermann D., Schmincke H.-U., 2000. Scoria cones and tuff rings. In: H. Sigurdsson (Ed.), Encyclopedia of volcanoes, Academic Press, San Diego: 683-694.

Vries B.V.W.D., Borgia A., 1996. The role of basement in volcano deformation. Geological Society, London, Special Publications 110(1): 95-110. DOI: 10.1144/GSL. SP.1996.110.01.07.

Walker G.P.L, Sigurdsson H., 2000. Basaltic volcanoes and volcanic systems. In: H. Sigurdsson (Ed.), Encyclopedia of volcapnoes, Academic Press, San Diego: 283-289 p.

Walker G.P.L., 1991. Structure, and origin by injection of lava under surface crust, of tumuli, "lava rises", "lava-rise pits", and "lava-inflation clefts" in Hawaii. Bulletin of Volcanology 53(7): 546-558.

Wohletz K.H., 1998. Pyroclastic surges and compressible two-phase flow. Chap. 7. In: Magma to Tephra. Elsevier, Amsterdam: 247-312.

Wohletz K.H., Mcql R.C., 1984. Experimental studies of hydromagmatic volcanism. Explosive Volcanism: Inception, Evolution, and Hazards: 158-169.

Wohletz K.H., Sheridan M.F., 1983. Hydrovolcanic explosions; II, Evolution of basaltic tuff rings and tuff cones. American Journal of Science 283(5): 385-413. DOI: 10.2475/ ajs.283.5.385

Wood D.A., 1980. The application of a ThHfTa diagram to problems of tectonomagmatic classification and to establishing the nature of crustal contamination of basaltic lavas of the British Tertiary Volcanic Province. Earth and Planetary Science Letters 50(1): 11-30. 